Solid Earth Discuss., https://doi.org/10.5194/se-2018-140

Manuscript under review for journal Solid Earth

Discussion started: 13 February 2019

(C) Author(s) 2019. CC BY 4.0 License.

\title{
The building, shaping, and filling of an Upper Slope Terrace: the Rio Grande Terrace, SW Atlantic
}

Michel Michaelovitch de Mahiques ${ }^{1,2}$, Javier Alcántara-Carrió ${ }^{1}$, Francisco José Lobo ${ }^{3}$,Uri Schattner $^{4}$,

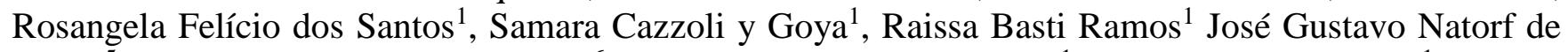

5 Abreu $^{5}$, Luiz Antonio Pereira de Souza ${ }^{6}$, Rubens Cesar Lopes Figueira ${ }^{1}$, Marcia Caruso Bícego ${ }^{1}$

${ }^{1}$ Oceanographic Institute, University of São Paulo, São Paulo, 05508-120, Brazil

${ }^{2}$ Institute of Energy and Environment, University of São Paulo, São Paulo, 05508-010, Brazil

${ }^{3}$ Instituto Andaluz de Ciencias de la Tierra, Armilla, 18100, Spain

${ }^{4}$ Leon H Charney School of Marine Sciences, University of Haifa, Haifa, 3498838, Israel

$10 \quad{ }^{5}$ Escola do Mar, Ciência e Tecnologia, UNIVALI, Itajaí, 88302-901, Brazil

${ }^{6}$ Instituto de Pesquisas Tecnológicas do Estado de São Paulo, São Paulo, 05508-901, Brazil

Correspondence to: Michel M. de Mahiques (mahiques@usp.br)

Abstract. In this work, we analyze the origin, evolution, and recent sedimentation of the Rio Grande Terrace (RGT), the

15 most prominent upper slope terrace of the SW Atlantic. We gathered data from deep to shallow seismic, echo-sounding and surface sediments in order to recognize the role played by the geological inheritance, the sediment origin, and the present hydrodynamics, this last one defined by the action of the high speeds of the Brazil Current.

The RGT is here interpreted as a unique geomorphological feature, which was developed over a pre-Aptian basement high. It presents a complex modern morphology, given by the erosional action of the Brazil Current and its present surface sediments show a high complexity in terms of origin and grain size.

\section{Introduction}

Upper continental slope sand deposits occur in different environments, such as carbonate reefs (Harris and Davies, 1989; Lidz, 2006) or previously glaciated areas (O'Reilly et al., 2007), formed or not in phases of sea-level stabilization (Øvrebø et al., 2006). They can be formed in active (Klaeschen et al., 1994; Dobson et al., 1998; Davy and Collot, 2000) or passive

(Kenyon, 1986; Weaver et al., 2000) tectonic margins.

On passive, siliciclastic margins, the development of upper slope sand deposits has been associated to the interaction of superficial boundary currents with the ocean bottom (Viana and Faugères, 1998; Viana et al., 1998; Viana et al., 2002). Rodriguez and Anderson (2004) identified an extensive sand deposit on the Antarctica outer shelf and upper slope, formed in the last ca. 9,000 years, and associated it to the action of the Circumpolar Deep Water. 
Solid Earth Discuss., https://doi.org/10.5194/se-2018-140

Manuscript under review for journal Solid Earth

Discussion started: 13 February 2019

(c) Author(s) 2019. CC BY 4.0 License.

In the case of the SW Atlantic slope, the maintenance of these features was attributed to the "floor-polisher" effect of the Brazil Current (de Mahiques et al., 2002; Viana et al., 2002), forming upper slope terraces. Hernández-Molina et al. (2008) refer these terraces as one of the six different large-scale erosional features associated with contourites. According to Kowsmann and Carvalho (2001), these terraces have been formed during the last lowstand and permitted the removal of

5 approximately 40 meters of sediment in the Campos Basin.

Deeper terraces also occur in the world margins, being associated either with tectonic controls (Hernández-Molina et al., 2006) or with the interaction between moving water masses and currents (Preu et al., 2013; Hernández-Molina et al., 2015).

On the SW Atlantic upper margin, a series of erosion terraces occur, in which the most prominent is the Rio Grande Terrace (RGT) (Zembruscki, 1979; Bassetto et al., 2000). Until the present days, the only papers that dealt with this important

10 geomorphological feature are related almost exclusively to the occurrence of phosphorite deposits on its northern part (Cooke et al., 2007; Pinho et al., 2011; Abreu et al., 2014; Pinho et al., 2015).

This study aims to provide the first characterization of the RGT, regarding its morphostructure and recent sedimentation, as an attempt to recognize the role of geological heritage and modern hydrodynamics in its present configuration.

\section{Study Area}

The RGT (Fig. 1) is a 5,500 km2 erosional terrace located between the latitudes $29^{\circ} 00^{\prime} \mathrm{S}$ and $31^{\circ} 00^{\prime} \mathrm{S}$ and longitudes $47^{\circ} 30^{\prime} \mathrm{W}$ and 48'30'W (Zembruscki, 1979; Bassetto et al., 2000). Its first morphological characterization was done by Zembruscki (1979), based on echosounder records from the 1960s and 1970s. The author defined the RGT as a horizontal feature located over the Torres Arch (Rabinowitz and LaBrecque, 1979; Meisling et al., 2001), positioned between the shelf break and the

20 lower slope. The author also described the morphology as marked by a rough surface, cut by valleys.

The limited information about its sedimentary structure and infill is based on the regional works by Kowsmann et al. (1977), Bassetto et al. (2000), and Stica et al. (2014).

Kowsmann et al. (1977) analyzed seismic refraction lines from southern Brazil, including some near the RGT (Fig. 1 and 2). The authors identified a high-velocity (> $6.0 \mathrm{~km} . \mathrm{s}-1)$ shallow feature on the area, interpreting it as a dike, associated with the

25 Torres Arch (Gladczenko et al., 1997). A whole sequence from Lower Cretaceous to Pliocene sediments was interpreted on the base of acoustic and well log data (Fig. 2A and B).

Stica et al. (2014), using deep-seismic and magnetic anomalies values, interpreted the occurrence of a volcanic dome, positioned just below the Terrace, deforming rift sediments. This dome should correspond to the same high-velocity feature described by Kowsmann et al. (1977).

30 Apart of the papers by Pinho et al. (2011), Pinho et al. (2015) and Figueiredo and Tessler (2004), there is no information about the sedimentary cover in the area. The first two papers used echosounder backscatter values to describe the prevalence of high Bottom Surface Backscattering Strength (BSBS) values in the area, associating them with the abundance of 
Solid Earth Discuss., https://doi.org/10.5194/se-2018-140

Manuscript under review for journal Solid Earth

Discussion started: 13 February 2019

(c) Author(s) 2019. CC BY 4.0 License.

phosphorite and carbonate-rich bottoms. Information about grain size and calcium carbonate content, available in Figueiredo and Tessler (2004) is based on very few samples, reporting the occurrence of carbonate-rich fine to medium sands.

Concerning information on circulation, there is no direct information about current speed and direction in the area. Nevertheless, since the RGT is located to the south of the Santos Bifurcation, it is admissible a general southward flow of the

5 current systems, from the outer shelf to the lower slope (Boebel et al., 1999; Schmid et al., 2000; Valla et al., 2018).

There is no adjacent river with significant input of sediments and a single sediment sample (578 $\mathrm{m}$ water depth) located farther north, and analyzed by Razik et al. (2015), indicates a mixed influence of the Plata mudbelt (Uruguayan shelf), together with the Pampean (Argentina) shelf, as potential sediment sources to the area.

\section{Methods}

10 The data used in this work is based on previously obtained acoustic lines and samples, as well as on information collected during an oceanographic survey on board R.V. Alpha Crucis, belonging to the University of São Paulo (Brazil), held in November-December 2017. All of the information regarding data is summarized in Fig.1.

Eight lines of high-resolution single-beam bathymetry were provided by the Brazilian Navy, under the auspices of the Program of Recognition of the Jurisdictional Continental Shelf (Mohriak and Torres, 2017). Each geographical coordinate

15 was transformed to UTM values (WGS84), and depth versus distance graphs were drawn. Changes in declivity were calculated using the mobile mean of ten sequential echo-sounding data.

Eight 2D time-migrated multi-channel seismic reflection profiles were released for academic use by the National Agency for Oil, Natural Gas, and Biofuels (ANP-Brazil). The .sgy files were analyzed in Petrel software. The age of selected reflectors was based on the interpretation from other sources (Kowsmann et al., 1977; Contreras et al., 2010; Anjos-Zerfass et al.,

20 2013; Morales et al., 2017).

Ten lines of sub-bottom records using a 3260 Knudsen $3.5 \mathrm{kHz}$ profiler (Fig.1) were obtained during a cruise onboard R.V. Alpha Crucis, between 30 November and 05 December 2017; Knudsen-proprietary .keb files were transformed into the .sgy format and analyzed using Meridata SVIEW and MDPS softwares. Additionally, the same survey lines were performed with a Teledyne RDI $75 \mathrm{kHz}$ ADCP for water current. Magnitude and direction of current speeds were filtered for the removal of

25 spikes, gridded using the natural neighbor interpolation, and vector maps of currents were performed for surface and 200 meters water depth, using software Surfer® Version 13.

Box-core samples were taken on the previously cited cruise as well as in another cruise, held in 2007, onboard R.V. Prof. W. Besnard (University of São Paulo, Brazil). The location of the samples is presented in Table 1 and Fig.1. Each box-core was sub-sampled continuously at intervals of 2-cm and each sub-sample was kept frozen for later freeze-drying. Only the surface

$30(0-2 \mathrm{~cm})$ sections were analyzed for this study.

The grain-size analysis was performed in sediment samples, after the removal of the calcium carbonate fraction with a solution of $10 \% \mathrm{HCl}$, removal of organic matter with a solution of $30 \%$ of hydrogen peroxide, and the addition of a solution 
Solid Earth Discuss., https://doi.org/10.5194/se-2018-140

Manuscript under review for journal Solid Earth

Discussion started: 13 February 2019

(c) Author(s) 2019. CC BY 4.0 License.

of 25\% sodium hexametaphosphate. Each sample was then analyzed under a Malvern Mastersizer 2000 Laser Analyser and grain-size parameters were calculated using the Gradistat @ MS-Excel macro (Blott and Pye, 2001). The sand fraction of each sample was analyzed under a stereomicroscope, in order to evaluate their siliciclastic or phosphoritic character.

Based on the optical analysis, the sandy fraction was classified according to four groups: 1) Siliciclastic with less than $20 \%$

5 of phosphorite, 2) Siliciclastic with $20 \%$ to $50 \%$ of oxidized phosphorite, 3) $50 \%$ - $80 \%$ of oxidized phosphorite and, 4) Oxidized phosphoritic sand.

Metals (Al, Ba, Ca, Cr, Cu, K, Fe, Mg, Mn, Mo, Sc, Sr, Ti, Zn) were analyzed in a Varian 710 ICP-OES, using the protocols of complete digestion established by the US Environmental Protection Agency 3052 Method. A detailed description of the analytical procedures is described in dos Santos et al. (2018).

10 Statistical analyses were performed using the software Past, version 3.20 (Hammer et al., 2001). Due to the lack of normality of the data, the correlation analyses were performed using the Spearman $\rho$ values.

For metals, we also performed a Principal Component Analysis, using standardized values $\left(\mathrm{x}^{-}=0, S= \pm 1\right)$, in order to identify the elements responsible for the highest variability in the area.

Finally, we also used some Metal/Metal ratios in order to recognize the relative influence of terrigenous materials $(\mathrm{Fe} / \mathrm{Ca})$

15 (Arz et al., 1999; Jennerjahn et al., 2004), the origin of the terrigenous fraction (Fe/K, Mg/Al) (Singh, 2011; Govin et al., 2012; Razik et al., 2015), and the characteristics of the carbonate fraction ( $\mathrm{Sr} / \mathrm{Ca}, \mathrm{Mg} / \mathrm{Ca}$ ) (Bayon et al., 2007).

\section{Results}

\subsection{Morphology}

The morphology of the RGT is widely diverse. To the south (figures 3A and 3B) the terrace is almost absent, giving place to

20 a steep scarp $\left(>5^{\circ}\right)$ at ca. 500 meters water depth.

In its central part (figures 3C, 3D, and 3E), the RGT is well developed, showing two smaller terraces, separated by a scarp at 300 meters (3D, 3E). The previously cited 500 meter-scarp gives place to a very rough surface, which extends down to the 1000 -meters isobath. In profiles 3D and 3E, the base of the RGT is marked by the presence of a very irregular, mounded bottom, with declivities reaching up to $10 \mathrm{o}$ and low penetration of the acoustic signal.

25 To the north, the RGT gives place to a surface marked by low-amplitude oscillations of declivity (figures $3 \mathrm{~F}, 3 \mathrm{G}$, and $3 \mathrm{H}$ ), marking the presence of kilometer-scale terraces, scarps, and depressions. A more detailed observation of the subbottom structures in this sector (Figure 4) shows an irregular pattern of scours cutting offshoreward inclined strata.

\subsection{Seismic}

A cross-RGT deep seismic line is shown in Figure 5. As references, we marked both the Serravallian (Mid-Miocene) 30 Unconformity as well as the Pre-Aptian basement. At its inner part, the seismic section presents about 5 sec (TWT) of strongly fractured prograding seismic units. The basal Unit (Late Cretaceous) is marked by strong deformation and faulting. 
Solid Earth Discuss., https://doi.org/10.5194/se-2018-140

Manuscript under review for journal Solid Earth

Discussion started: 13 February 2019

(c) Author(s) 2019. CC BY 4.0 License.

Paleogene and Oligocene units present low amplitude and progradational terminations. To offshore, out of the RGT, these units are truncated by a strong erosional surface and a distinct set of wedge-like units is deposited.

The topmost Unit (see detail in Figure 5) corresponds to a clinoform, located at the edge of the RGT, deposited over eroded post-Serravalian (Plio-Pleistocene?) deposits. It is possible to recognize, inside this clinoform, at least seven high-amplitude

5 reflectors. On the other hand, the top of this clinoform also presents truncation over originally toplap terminations.

The interpreted total isopach and Pre-Aptian depth map (Figures 6A and B) clearly indicate that the RGT lays on a basement high, which is projected from the continent towards ENE. In its thinner part, the RGT presents a thickness equivalent to no more than $2.5 \mathrm{sec}$ (TWT), corresponding to half of the thickness of adjacent areas.

\subsection{Hydrodynamics, Sedimentology and Geochemistry}

10 Current speed and directions, obtained during the December 2017 cruise indicate the prevalence of a high-speed southward flow, at least from the sea surface until the 200-m isobath (Figures 7A and 7B).

A summary of the sedimentological and geochemical results is presented in Supplementary Material 1.

Grain size data reveal a whole range from sands to silts, with clay becoming a subsidiary class (Figure 8). Sandy sediments occupy the widest, less steep areas of the RGT; on the other hand, sandy silts and silts are more abundant to the north, as

15 well as on the shelf and in water depths higher than 500 meters.

Concerning the sand characteristics, the samples from the center of the RGT are mostly rich in oxidized phosphorite (Supplementary Material 2). The amount of phosphoritic sands decreases towards the extremes of the area, and a single sample shows black (non-oxidized phosphorite) in its sandy fraction.

The analysis of the grain size distribution curves (Figure 9) indicates a wide variability of distributions, from unimodal to

20 trimodal, poorly sorted sediments. Grain size main medians vary from $3.8 \phi$ (very fine sand) to $8.8 \phi$ (very fine silt). There is a general trend of fining grain size towards deeper areas. Samples located in the south, between 300 and 500 meters, present a conspicuous mode at fine to very fine sand.

Table 2 presents the Spearman $\rho$ correlation values between elements, percentage of sand and clay, and water-depth, in which it is possible to recognize four clusters, i.e., $\mathrm{Ca}$ and $\mathrm{Sr}, \mathrm{Al}$ and $\mathrm{Sc}, \mathrm{Ba}$ and $\mathrm{Cu}$, and $\mathrm{Cr}, \mathrm{Cu}, \mathrm{Fe}, \mathrm{K}, \mathrm{Mg}, \mathrm{Mn}, \mathrm{Ni}$, Ti, and $25 \mathrm{Zn}$.

The first two components of the Principal Component Analysis account for 61.5\% of the total variance (Figure 10). The first component (42.1\% of the total variance) is highly influenced by the contents in $\mathrm{Fe}, \mathrm{Ni}$, and $\mathrm{Cr}$, and, secondarily, by the contents in $\mathrm{K}, \mathrm{Ti}$, and $\mathrm{Zn}$. The second component (19.4\% of the total variance) opposes $\mathrm{Ca}$ and $\mathrm{Sr}$ against $\mathrm{Ba}$ and $\mathrm{Cu}$.

Most of the samples show Fe/Ca ratio lower than 0.5 (Figure 11), indicating the prevalence of biogenic sediments in the area. The highest $\mathrm{Fe} / \mathrm{Ca}$ ratio values are present on the shallower samples, as well as those located on the top of the RGT, these last associated with the presence of Fe-rich phosphorites.

The scatter plot of $\mathrm{Fe} / \mathrm{K}$ versus $\mathrm{Mg} / \mathrm{Al}$ is also an indication of high compositional variability. Most of the shallower samples exhibit low values of both $\mathrm{Mg} / \mathrm{Al}$ and $\mathrm{Fe} / \mathrm{K}$, the lowest values corresponding to the samples with higher terrigenous input. 
Solid Earth Discuss., https://doi.org/10.5194/se-2018-140

Manuscript under review for journal Solid Earth

Discussion started: 13 February 2019

(c) Author(s) 2019. CC BY 4.0 License.

The scatter plot of $\mathrm{Sr} / \mathrm{Ca}$ versus $\mathrm{Mg} / \mathrm{Ca}$ (Figure 13) presents a $\mathrm{V}$-shaped distribution of the samples, with their concentration towards Mg-enriched (located on the center of the RGT), but distinct samples displaced either towards Sr-enriched (deepest samples in the south) or detrital carbonate (shallower samples).

\section{Discussion}

\section{$5 \quad 5.1$ Morphostructure and dynamics}

The complexity shown by the bathymetry of the RGT reflects a series of depositional, tectonic and recent hydrodynamic events that took place in the SW Atlantic margin that started during the rift phase and persists until now.

The RGT is sustained by a basement high, probably associated with the extension of the Torres Arch, over which a sequence of sediments, from the Aptian to the Plio-Pleistocene, was deposited. The presence of this high makes the RGT a unique

10 feature on the SW Atlantic upper slope terraces since none of the others seems to be sustained by basement projections (Viana and Faugères, 1998; Kowsmann and Carvalho, 2001).

The topmost strata present a clinoform, which upper surface is truncated and presents a sequence of scours with amplitudes of meters (Figure 5). Differently than proposed by Zembruscki (1979), these scours present a pattern which is parallel to the isobaths and cannot be associated with paleo-drainages. We propose that this truncation is associated with the high speed of

15 the Brazil Current; current velocities have never been measured before our work, but the competence of the Brazil Current has been already attested previously to the north of the area (Viana et al., 2002; Duarte and Viana, 2007; Biló et al., 2014; Schattner et al., 2016).

\subsection{Sediment source and distribution}

Both grain-size and sediment composition data indicate that different sources contribute with sediments to the RGT. In the

20 grain-size, this is characterized by the presence of distinct modes and a wide grain size variability, represented by the large spectrum of medians; concerning chemical composition, wide variability in major and minor elements is also evident.

The presence of phosphorite grains also indicates that the reworking of authigenic sediments may also be an important source of the sediments, especially between the 300 and 500-meters isobath.

Concerning the contribution of a biogenic fraction, the prevalence of values of $\mathrm{Fe} / \mathrm{Ca}$ lower than 0.5 indicates that biogenic

25 constituents are also an important source of the sediments in the area. These values are lower than those reported for the dry conditions of NE Brazil (Jennerjahn et al., 2004), indicating that the direct input of modern sediments from the adjacent continent is limited and probably restricted to the shallower samples. Nevertheless, our values are compatible with those reported by Govin et al. (2012), to the same area of the SW Atlantic.

Still, concerning the biogenic fraction, it is noticeable that, despite the prevalence of Mg-enriched carbonates, some samples

30 exhibit a higher content of $\mathrm{Sr}$, suggesting the partial occurrence of aragonite and detrital carbonates (Figure 13). The 
Solid Earth Discuss., https://doi.org/10.5194/se-2018-140

Manuscript under review for journal Solid Earth

Discussion started: 13 February 2019

(c) Author(s) 2019. CC BY 4.0 License.

prevalence of Mg-enriched carbonates suggests the occurrence of gas escape in the RGT, aspect that was already reported to the south (Miller et al., 2015) and to the north (dos Santos et al., 2018) of the study area.

A scatter plot of the $\mathrm{Fe} / \mathrm{K}$ ratio versus the grain size median (Figure 14) shows a wide range in both parameters. The samples with higher $\mathrm{Fe} / \mathrm{K}$ ratios and coarser grain size correspond to the phosphorite-rich sediments. A distinct linear trend

5 is associated with finer medians, indicating different degrees of weathering in the sediment source areas (Razik et al., 2015). Worth to note that we cannot compare our results directly with the paper by Razik et al. (2015) since those authors used the whole grain-size distribution mean. In the RGT, the presence of sediments with very high Fe/K values might be associated with post-depositional processes, related to the formation of ferruginous phosphorites.

Concerning the Principal Component Analysis, the dispersal of samples towards different trends reveals the complexity of

10 sources of sediments in the area. Apart from the already cited biogenic fraction-enriched samples (higher $\mathrm{Ca}$ and $\mathrm{Sr}$ ), other sources are recognized. Relative enrichment of $\mathrm{Cu}$ and $\mathrm{Ba}$ can be associated with higher productivity (Von Breymann et al., 1990; Kumar et al., 1996) which is promoted by a shelf-break upwelling that is frequent in the area (Brandini, 1988, 1990). Finally, the $\mathrm{Fe}, \mathrm{Ni}$, and $\mathrm{Cr}$-enriched samples are associated with the presence of Fe-enriched phosphorites (Compton and Bergh, 2016; González et al., 2016).

15 Considering the aspects of the geological inheritance of a feature sustained by a basement high, the mixture of both lithogenic, biogenic, and authigenic sediments, and the reshaping of the morphology, given by the action of the Brazil Current on its shallower part, we recognize that the RGT consists of a unique feature, which is distinct than all of the other slope terraces of the SW Atlantic.

\section{Conclusions}

20 The Rio Grande Terrace (RGT) is the most conspicuous upper slope terrace of the SW Atlantic margin. Its origin is associated with the deposition of Late Cretaceous to Cenozoic sediments over an uplifted volcanic body. Its Late Cenozoic (Pleistocene?) corresponds to a clinoform that is truncated on its top. This truncation, marked by several isobaths-oriented scours, may be associated with the strong flow of the Brazil Current.

Surface sediments reveal a complex mosaic of sources and types, varying from fine sands do very fine silts, with unimodal to

25 trimodal distributions. The non-biogenic composition is also extremely variable and includes siliciclastic sediments and authigenic phosphorites. In this sense, the complex interaction of geological inheritance, sediment sources, and hydrodynamics led to the development of the RGT, a unique feature in the SW Atlantic.

\section{Acknowledgments}

The authors wish to thank the crew and researchers who participated in the Nov-Dec 2017 Survey onboard R.V. Alpha 30 Crucis. This work was funded by the São Paulo Science Foundation (FAPESP, grant 2016/22194-0). FAPESP also grants 
Solid Earth Discuss., https://doi.org/10.5194/se-2018-140

Manuscript under review for journal Solid Earth

Discussion started: 13 February 2019

(c) Author(s) 2019. CC BY 4.0 License.

the collaboration between MM de M and US (grant 2017/50191-8). MM de M acknowledges the Brazilian Research Council (CNPq), for the Research Grant 303132/2014-0. CNPq also supports the collaboration between MM de M and FJL (grant 401041/2014-0).

\section{References}

5 Abreu, J. G. N., Corrêa, I. C. S., Horn Filho, N. O., and Calliari, L. J.: Phosphorites of the Brazilian Continental Margin, Southwestern Atlantic Ocean, Revista Brasileira de Geofísica, 32, 539-548, 2014.

Anjos-Zerfass, G. S., Ruban, D. A., Chemale Jr, F., and Zerfass, H.: Cenozoic synthem stratigraphic architecture of the SE Brazilian shelf and its global eustatic context: evidence from the Pelotas Basin (offshore Brazil), Geologos, $19,2013$.

Arz, H. W., Pätzold, J., and Wefer, G.: Climatic changes during the last deglaciation recorded in sediment cores from the

10 northeastern Brazilian Continental Margin, Geo-Marine Letters, 19, 209-218, 1999.

Bassetto, M., Alkmim, F. F., Szatmari, P., and Mohriak, W. U.: The oceanic segment of the southern Brazilian margin: Morpho-structural domains and their tectonic significance. In: Atlantic Rifts and Continental Margins, Geophysical Monograph Series, 2000.

Bayon, G., Pierre, C., Etoubleau, J., Voisset, M., Cauquil, E., Marsset, T., Sultan, N., Le Drezen, E., and Fouquet, Y.: Sr/Ca

15 and $\mathrm{Mg} / \mathrm{Ca}$ ratios in Niger Delta sediments: Implications for authigenic carbonate genesis in cold seep environments, Marine Geology, 241, 93-109, 2007.

Biló, T. C., da Silveira, I. C. A., Belo, W. C., de Castro, B. M., and Piola, A. R.: Methods for estimating the velocities of the Brazil Current in the pre-salt reservoir area off southeast Brazil (23० S-26。 S), Ocean Dynamics, 64, 1431-1446, 2014.

Blott, S. J. and Pye, K.: GRADISTAT: a grain size distribution and statistics package for the analysis of unconsolidated 20 sediments, Earth Surface Processes and Landforms, 26, 1237-1248, 2001.

Boebel, O., Davis, R. E., Ollitrault, M., Peterson, R. G., Richardson, P. L., Schmid, C., and Zenk, W.: The intermediate depth circulation of the western South Atlantic, Geophysical Research Letters, 26, 3329-3332, 1999.

Brandini, F. P.: Hydrography and characteristics of the phytoplankton in shelf and oceanic waters off southeastern Brazil during winter (July/August 1982) and summer (February/March 1984), Hydrobiologia, 196, 111-148, 1990.

25 Brandini, F. P.: Hydrography, phytoplankton biomass and photosynthesis in shelf and oceanic waters off southeastern Brazil during autumn (May/June 1983), Boletim do Instituto Oceanográfico, 36, 63-72, 1988.

Compton, J. S., and Bergh, E. W.: Phosphorite deposits on the Namibian shelf, Marine Geology, 380, 290-314, 2016.

Contreras, J., Zühlke, R., Bowman, S., and Bechstädt, T.: Seismic stratigraphy and subsidence analysis of the southern Brazilian margin (Campos, Santos and Pelotas basins), Marine and Petroleum Geology, 27, 1952-1980, 2010.

30 Cooke, C. V., Madureira, L. S. P., Griep, G. H., and Pinho, M. P.: Análise de dados de ecossondagem de fundo oriundos de cruzeiros realizados entre Fortaleza (CE) e Chuí (RS) com enfoque na morfologia e tipos de fundo, Revista Brasileira de Geofísica, 25, 443-457, 2007. 
Solid Earth Discuss., https://doi.org/10.5194/se-2018-140

Manuscript under review for journal Solid Earth

Discussion started: 13 February 2019

(c) Author(s) 2019. CC BY 4.0 License.

Davy, B. and Collot, J. Y.: The Rapuhia Scarp (northern Hikurangi Plateau) — its nature and subduction effects on the Kermadec Trench, Tectonophysics, 328, 269-295, 2000.

de Mahiques, M. M., Almeida da Silveira, I. C., de Mello e Sousa, S. H., and Rodrigues, M.: Post-LGM sedimentation on the outer shelf-upper slope of the northernmost part of the São Paulo Bight, southeastern Brazil, Marine Geology, 181, 387-

$5400,2002$.

Dobson, M. R., O’Leary, D., and Veart, M.: Sediment delivery to the Gulf of Alaska: source mechanisms along a glaciated transform margin, Geological Society, London, Special Publications, 129, 43-66, 1998.

dos Santos, R. F., Nagaoka, D., Ramos, R. B., Salaroli, A. B., Taniguchi, S., Figueira, R. C. L., Bícego, M. C., Lobo, F. J., Schattner, U., and de Mahiques, M. M.: Metal/Ca ratios in pockmarks and adjacent sediments on the SW Atlantic slope:

10 Implications for redox potential and modern seepage, Journal of Geochemical Exploration, 192, 163-173, 2018.

Duarte, C. S. L. and Viana, A. R.: Santos Drift System: stratigraphic organization and implications for late Cenozoic palaeocirculation in the Santos Basin, SW Atlantic Ocean, Geological Society, London, Special Publications, 276, 171-198, 2007.

Figueiredo, A. G. and Tessler, M. G.: Topografia e composição do substrato marinho da região sudeste-sul do Brasil,

15 Instituto Oceanográfico - USP, São Paulo, 2004.

Gladczenko, T. P., Hinz, K., Eldholm, O., Meyer, H., Neben, S., and Skogseid, J.: South Atlantic volcanic margins, Journal of the Geological Society, 154, 465-470, 1997.

González, F. J., Somoza, L., Hein, J. R., Medialdea, T., León, R., Urgorri, V., Reyes, J., and Martín-Rubí, J. A.: Phosphorites, Co-rich Mn nodules, and Fe-Mn crusts from Galicia Bank, NE Atlantic: Reflections of Cenozoic tectonics and 20 paleoceanography, Geochemistry, Geophysics, Geosystems, 17, 346-374, 2016.

Govin, A., Holzwarth, U., Heslop, D., Ford Keeling, L., Zabel, M., Mulitza, S., Collins, J. A., and Chiessi, C. M.: Distribution of major elements in Atlantic surface sediments $\left(36^{\circ} \mathrm{N}-49^{\circ} \mathrm{S}\right)$ : Imprint of terrigenous input and continental weathering, Geochemistry, Geophysics, Geosystems, 13, n/a-n/a, 2012.

Hammer, Ø., Harper, D. A. T., and Ryan, P. D.: PAST: Paleontological statistics software package for education and data 25 analysis, Palaeontologia Electronica, 4, http://palaeo-electronica.org/2001_2001/past/issue2001_2001.htm 2001.

Harris, P. T. and Davies, P. J.: Submerged reefs and terraces on the shelf edge of the Great Barrier Reef, Australia, Coral Reefs, 8, 87-98, 1989.

Hernández-Molina, F. J., Llave, E., and Stow, D. A. V.: Chapter 19 Continental Slope Contourites. In: Contourites, Rebesco, M. and Camerlenghi, A. (Eds.), Developments in Sedimentology, Elsevier, 2008.

30 Hernández-Molina, F. J., Llave, E., Stow, D. A. V., García, M., Somoza, L., Vázquez, J. T., Lobo, F. J., Maestro, A., Díaz del Río, V., León, R., Medialdea, T., and Gardner, J.: The contourite depositional system of the Gulf of Cádiz: A sedimentary model related to the bottom current activity of the Mediterranean outflow water and its interaction with the continental margin, Deep Sea Research Part II: Topical Studies in Oceanography, 53, 1420-1463, 2006. 
Solid Earth Discuss., https://doi.org/10.5194/se-2018-140

Manuscript under review for journal Solid Earth

Discussion started: 13 February 2019

(C) Author(s) 2019. CC BY 4.0 License.

Hernández-Molina, F. J., Soto, M., Piola, A. R., Tomasini, J., Preu, B., Thompson, P., Badalini, G., Creaser, A., Violante, R. A., Morales, E., Paterlini, M., and De Santa Ana, H.: A contourite depositional system along the Uruguayan continental margin: Sedimentary, oceanographic and paleoceanographic implications, Marine Geology, doi: 10.1016/j.margeo.2015.10.008, 2015. 2015.

5 Jennerjahn, T. C., Ittekkot, V., Arz, H. W., Behling, H., Patzold, J., and Wefer, G.: Asynchronous terrestrial and marine signals of climate change during Heinrich events, Science, 306, 2236-2239, 2004.

Kenyon, N. H.: Evidence from bedforms for a strong poleward current along the upper continental slope of northwest Europe, Marine Geology, 72, 187-198, 1986.

Klaeschen, D., Belykh, I., Gnibidenko, H., Patrikeyev, S., and von Huene, R.: Structure of the Kuril Trench from seismic 10 reflection records, Journal of Geophysical Research: Solid Earth, 99, 24173-24188, 1994.

Kowsmann, R. O. and Carvalho, M. D.: Erosional event causing gas-venting on the upper continental slope, Campos Basin, Brazil, Continental Shelf Research, 22, 2345-2354, 2001.

Kowsmann, R. O., Leyden, R., and Francisconi, O.: Marine Seismic investigations, Southern Brazil Margin, AAPG Bulletin, $61,546-557,1977$.

15 Kumar, N., Anderson, R. F., and Biscaye, P. E.: Remineralization of particulate authigenic trace metals in the middle Atlantic Bight: Implications for proxies of export production, Geochimica et Cosmochimica Acta, 60, 3383-3397, 1996.

Lidz, B. H.: Pleistocene Corals of the Florida Keys: Architects of Imposing Reefs_-Why?, Journal of Coastal Research, 224, 750-759, 2006.

Meisling, K. E., Cobbold, P. R., and Mount, V. S.: Segmentation of an obliquely rifted margin, Campos and Santos basins, 20 southeastern Brazil, AAPG Bulletin, 85, 1903-1924, 2001.

Mohriak, W. U. and Torres, L. C.: Levantamentos geofísicos para a delimitação da margem continental brasileira, Revista USP, 113, 59-80, 2017.

Morales, E., Chang, H. K., Soto, M., Corrêa, F. S., Veroslavsky, G., de Santa Ana, H., Conti, B., and Daners, G.: Tectonic and stratigraphic evolution of the Punta del Este and Pelotas basins (offshore Uruguay), Petroleum Geoscience, 23, 415-426,

252017.

O'Reilly, B. M., Shannon, P. M., and Readman, P. W.: Shelf to slope sedimentation processes and the impact of PlioPleistocene glaciations in the northeast Atlantic, west of Ireland, Marine Geology, 238, 21-44, 2007.

Øvrebø, L. K., Haughton, P. D. W., and Shannon, P. M.: A record of fluctuating bottom currents on the slopes west of the Porcupine Bank, offshore Ireland — implications for Late Quaternary climate forcing, Marine Geology, 225, 279-309, 2006.

30 Pinho, M. P., Madureira, L. S. P., and Calliari, L. J.: 3D Bathymetry and Bottom Backscattering Maps Applied to Identify Potential Phosphate Deposits in the Pelotas Basin, Brazil, IEEE/OES ACOUSTICS IN UNDERWATER GEOSCIENCES SYMPOSIUM, Rio de Janeiro, 2015. 
Solid Earth Discuss., https://doi.org/10.5194/se-2018-140

Manuscript under review for journal Solid Earth

Discussion started: 13 February 2019

(C) Author(s) 2019. CC BY 4.0 License.

Pinho, M. P., Madureira, L. S. P., Calliari, L. J., Griep, G. H., and Cooke, C. V.: Depósitos fosfáticos marinhos na costa sudeste e sul do Brasil: Potenciais de ocorrência identificadas com dados de retroespalhamento acústico do fundo e sedimentológicos analisados sobre mapa batimétrico 3D, Revista Brasileira de Geofísica, 29, 113-126, 2011.

Preu, B., Hernández-Molina, F. J., Violante, R., Piola, A. R., Paterlini, C. M., Schwenk, T., Voigt, I., Krastel, S., and Spiess,

5 V.: Morphosedimentary and hydrographic features of the northern Argentine margin: The interplay between erosive, depositional and gravitational processes and its conceptual implications, Deep Sea Research Part I: Oceanographic Research Papers, 75, 157-174, 2013.

Rabinowitz, P. D. and LaBrecque, J.: The Mesozoic South Atlantic Ocean and evolution of its continental margins, Journal of Geophysical Research, 84, 1979.

10 Razik, S., Govin, A., Chiessi, C. M., and von Dobeneck, T.: Depositional provinces, dispersal, and origin of terrigenous sediments along the SE South American continental margin, Marine Geology, 363, 261-272, 2015.

Rodriguez, A. B. and Anderson, J. B.: Contourite origin for shelf and upper slope sand sheet, offshore Antarctica, Sedimentology, 51, 699-711, 2004.

Schattner, U., Lazar, M., Souza, L. A. P., ten Brink, U., and Mahiques, M. M.: Pockmark asymmetry and seafloor currents in

15 the Santos Basin offshore Brazil, Geo-Marine Letters, 36, 457-464, 2016.

Schmid, C., Siedler, G., and Zenk, W.: Dynamics of Intermediate Water Circulation in the Subtropical South Atlantic, Journal of Physical Oceanography, 30, 3191-3211, 2000.

Singh, P.: Weathering and chemical variability in Ganga Plain sediments. In: Geological processes and climate change, Singh, D. S. and Chhabra, N. L. (Eds.), McMillan, India, 2011.

20 Stica, J. M., Zalán, P. V., and Ferrari, A. L.: The evolution of rifting on the volcanic margin of the Pelotas Basin and the contextualization of the Paraná-Etendeka LIP in the separation of Gondwana in the South Atlantic, Marine and Petroleum Geology, 50, 1-21, 2014.

Valla, D., Piola, A. R., Meinen, C. S., and Campos, E.: Strong Mixing and Recirculation in the Northwestern Argentine Basin, Journal of Geophysical Research: Oceans, doi: 10.1029/2018jc013907, 2018. 2018.

25 Viana, A. R., De Almeida, W., and De Almeida, C. W.: Upper slope sands: Late Quaternary shallow-water sandy contourities of Campos Basin, SW Atlantic Margin, Geological Society, London, Memoirs, 22, 261-270, 2002.

Viana, A. R. and Faugères, J. C.: Upper slope sand deposits: the example of Campos Basin, a latest Pleistocene-Holocene record of the interaction between alongslope and downslope currents, Geological Society, London, Special Publications, 129, 287-316, 1998.

30 Viana, A. R., Faugères, J. C., and Stow, D. A. V.: Bottom-current-controlled sand deposits - a review of modern shallowto deep-water environments, Sedimentary Geology, 115, 53-80, 1998.

Von Breymann, M. T., Suess, E., and Lyle, M. W.: Depth dependent enrichment of barium and copper in the Peru margin and Nazca Plate sediments; utility as productivity proxies, EOS Transactions, 71, 116-117, 1990. 
Solid Earth Discuss., https://doi.org/10.5194/se-2018-140

Manuscript under review for journal Solid Earth

Discussion started: 13 February 2019

(c) Author(s) 2019. CC BY 4.0 License.

(c) (1)

Weaver, P. P. E., Wynn, R. B., Kenyon, N. H., and Evans, J.: Continental margin sedimentation, with special reference to the north-east Atlantic margin, Sedimentology, 47, 239-256, 2000.

Zembruscki, S. G.: Geomorfologia da margem continental sul brasileira e das bacias oceânicas adjacentes. In: Geomorfologia da margem continental brasileira e áreas oceânicas adjacentes, Chaves, H. A. F. (Ed.), 7, Petrobrás, Rio de 5 Janeiro, 1979.

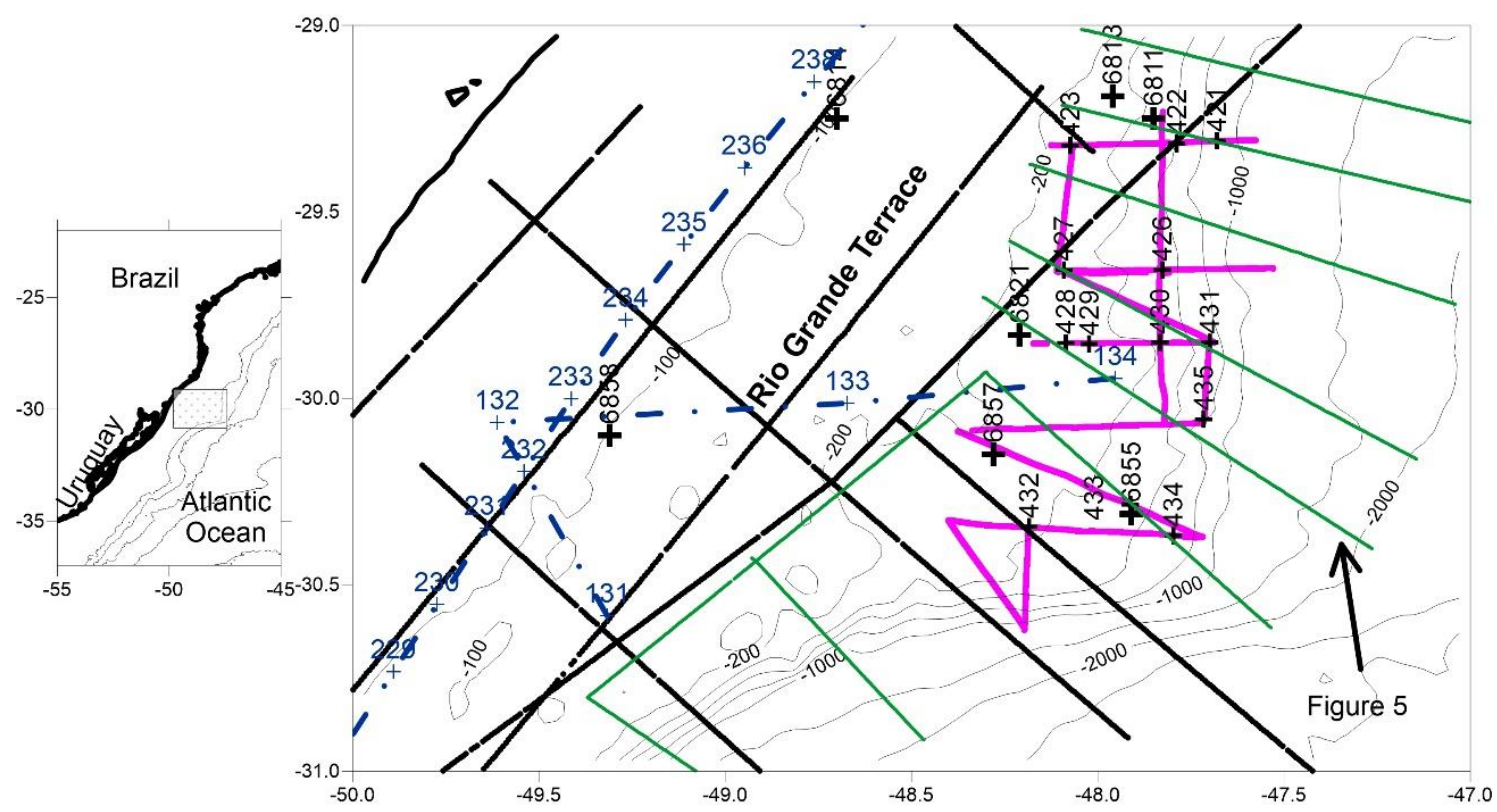

Figure 1: Location of the study area, seismic refraction lines (Kowsmann et al., 1977, dashed blue), deep seismic reflection lines (black), echosounding lines (green), chirp and ADCP lines (magenta), and samples analyzed in this work. 
Solid Earth Discuss., https://doi.org/10.5194/se-2018-140

Manuscript under review for journal Solid Earth

Discussion started: 13 February 2019

(c) Author(s) 2019. CC BY 4.0 License.
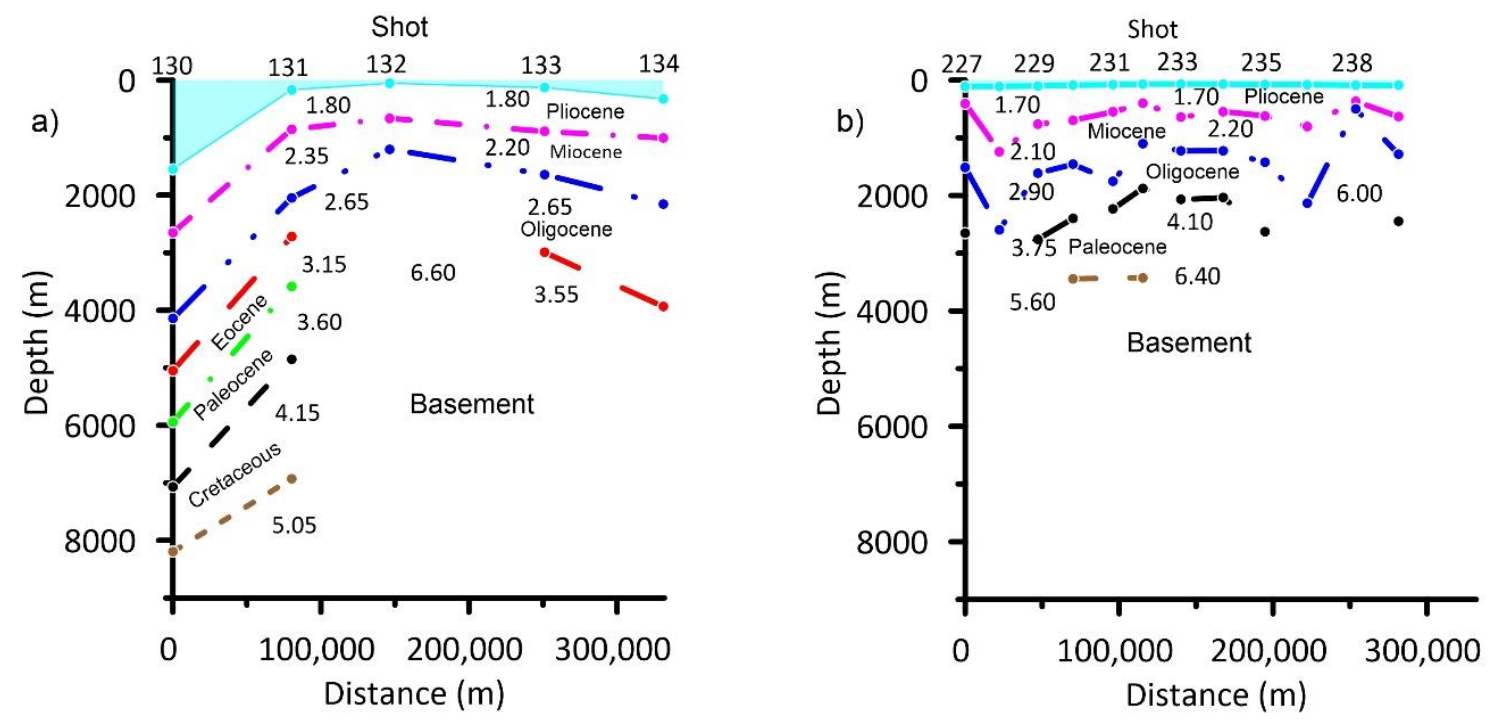

Figure 2: Interpretation of seismic refraction lines as presented in Kowsmann et al. (1977). For position of the shooting lines refer to Figure 1. 
Solid Earth Discuss., https://doi.org/10.5194/se-2018-140

Manuscript under review for journal Solid Earth

Discussion started: 13 February 2019

(c) Author(s) 2019. CC BY 4.0 License.

\section{(c) (1)}
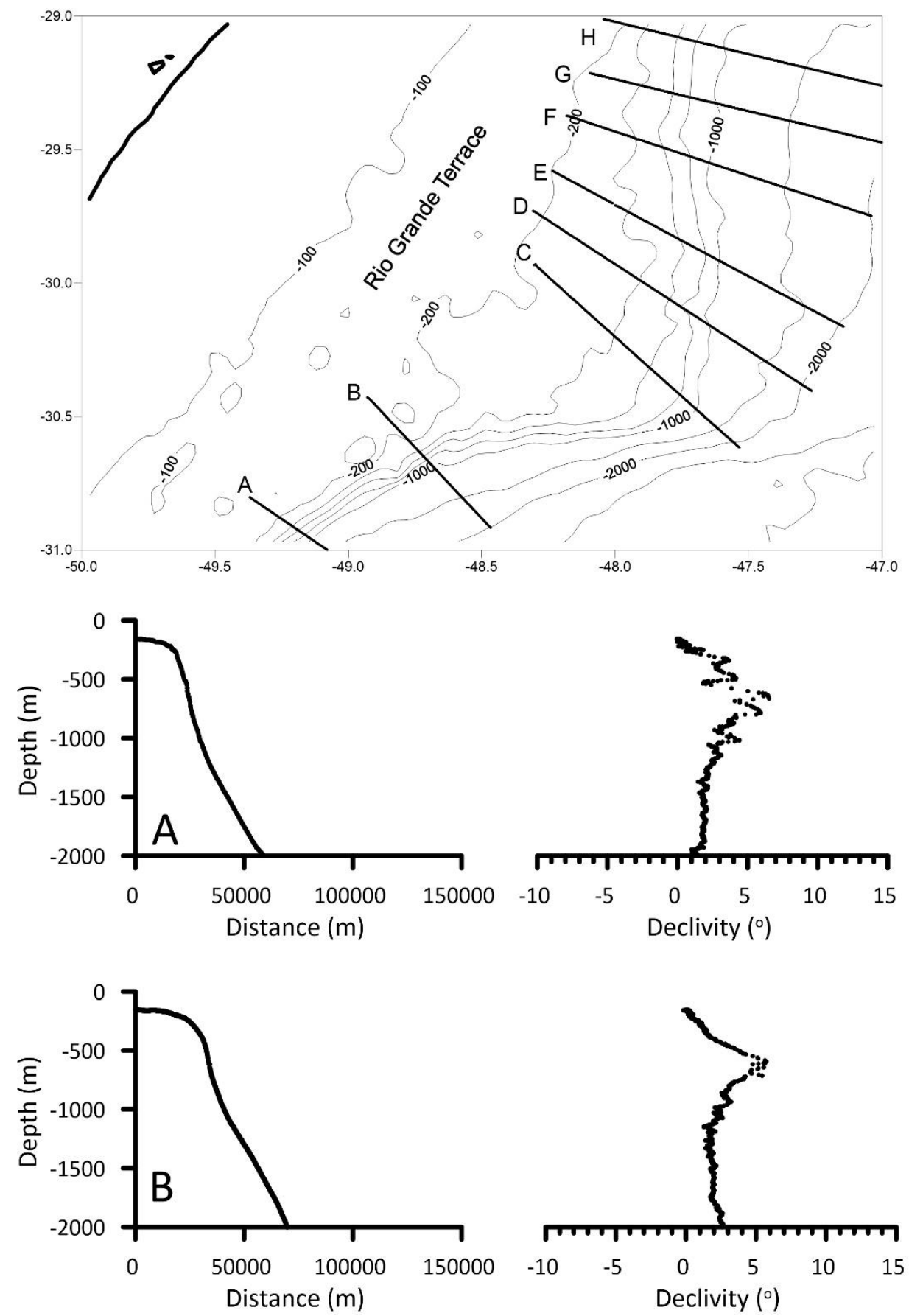

Figure 3: Bathymetrical (left) and declivity profiles of the echosounding lines provided by the Brazilian Navy. Location of each profile is shown in the topmost figure. 

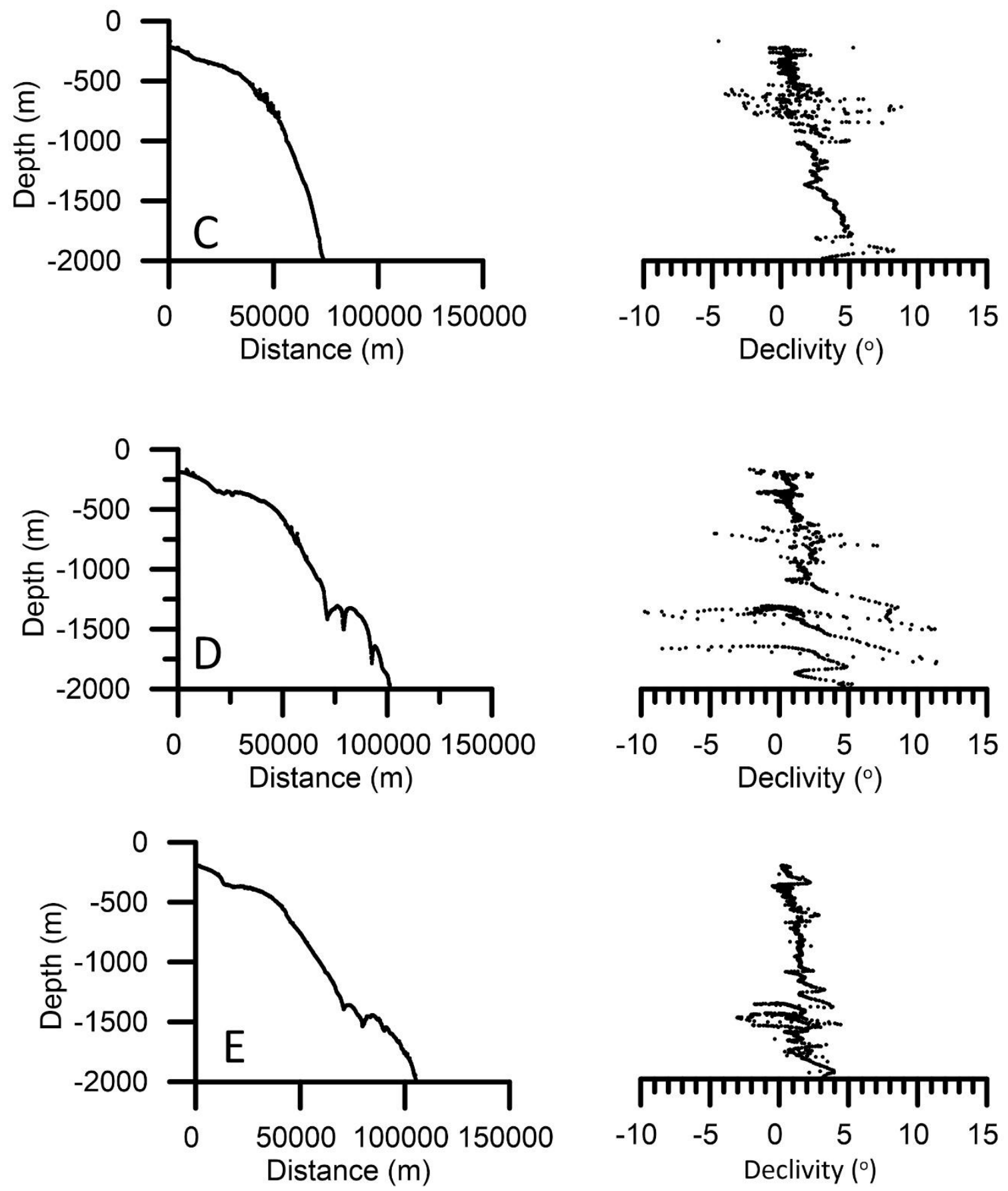

Figure 3: (cont.)

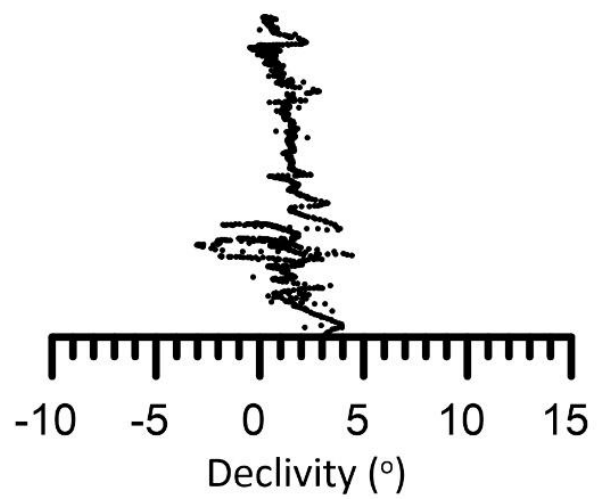


Solid Earth Discuss., https://doi.org/10.5194/se-2018-140

Manuscript under review for journal Solid Earth

Discussion started: 13 February 2019

(c) Author(s) 2019. CC BY 4.0 License.

(c) $\stackrel{(1)}{(x)}$
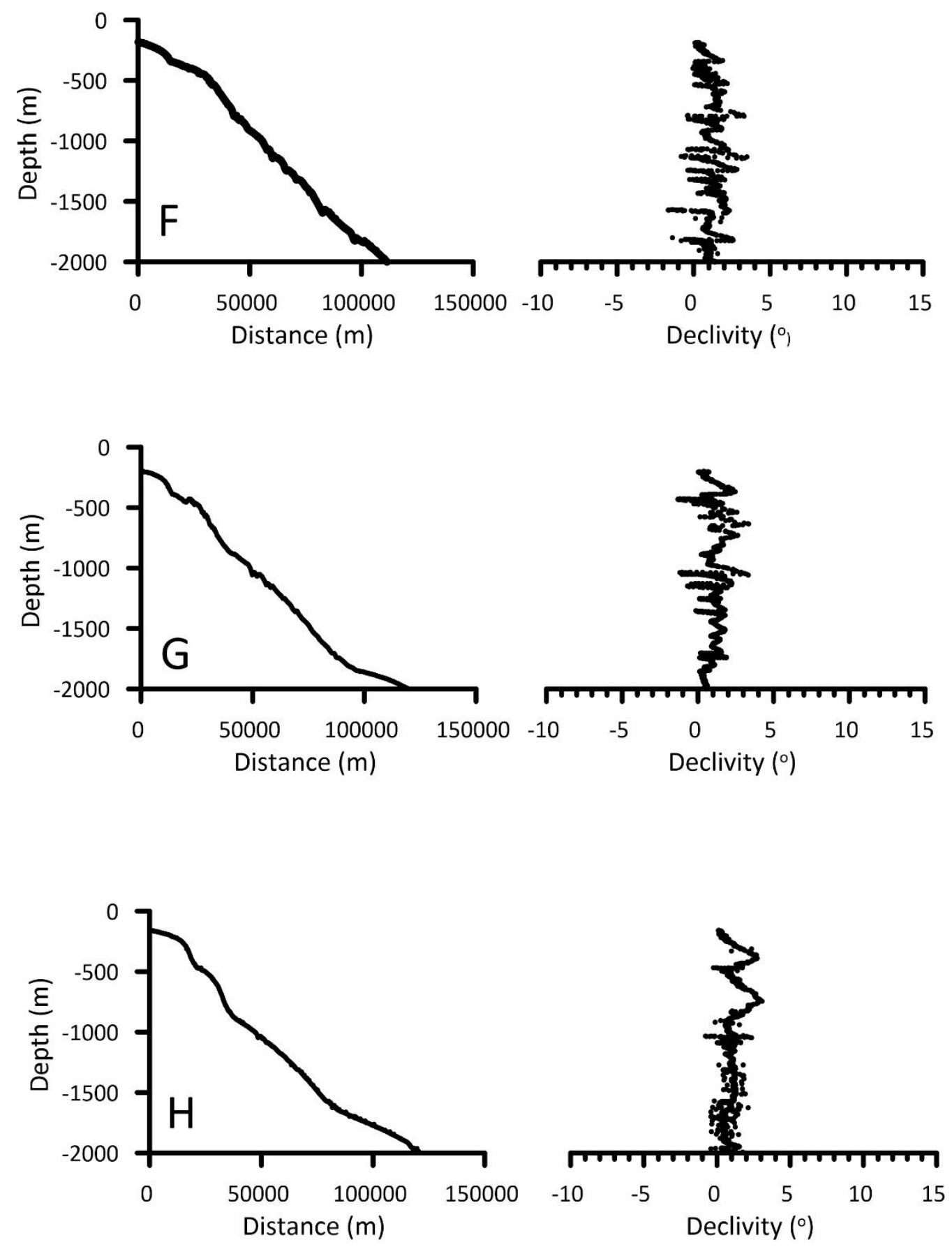

Figure 3: (cont.) 
Solid Earth Discuss., https://doi.org/10.5194/se-2018-140

Manuscript under review for journal Solid Earth

Discussion started: 13 February 2019

(c) (i)

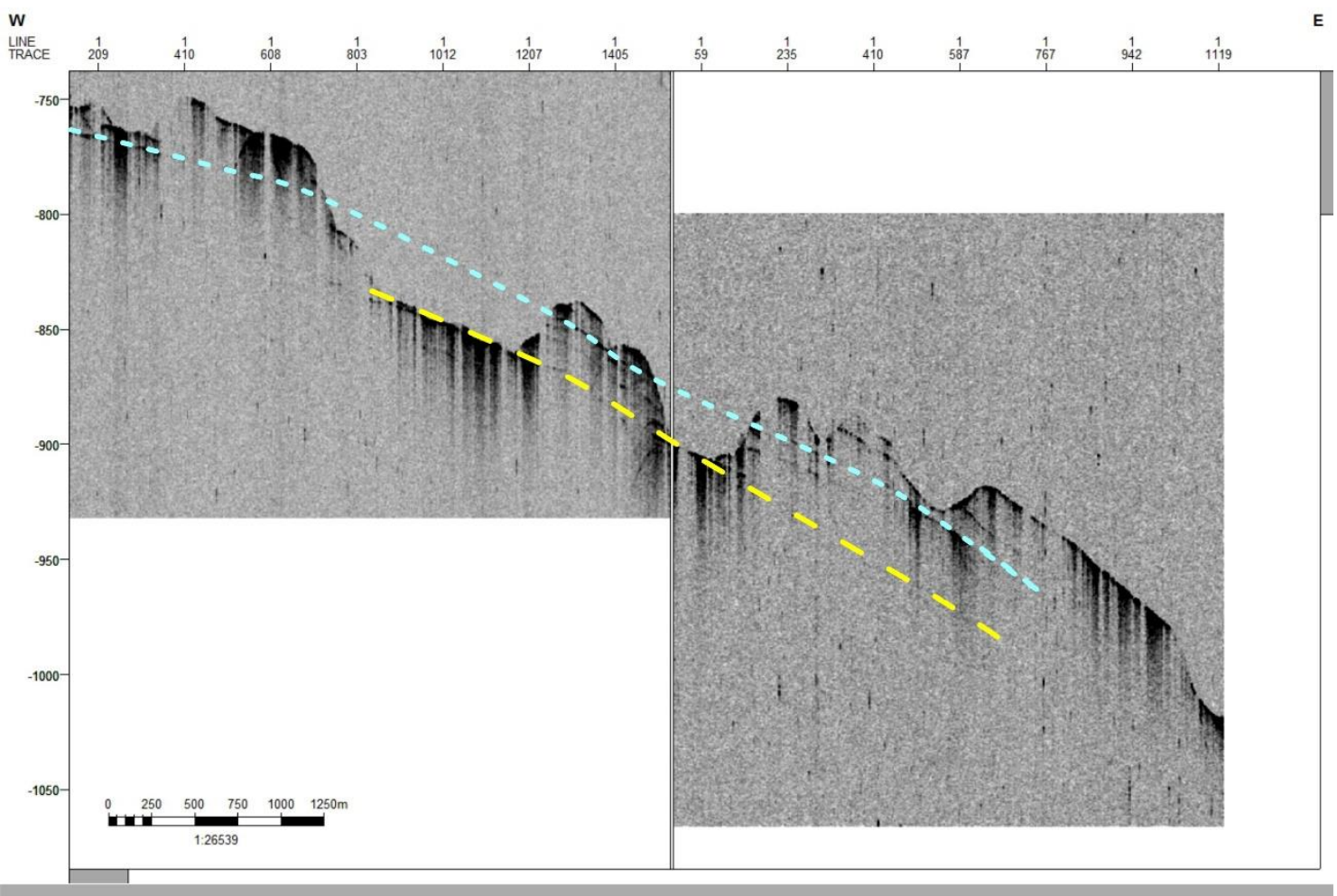

Figure 4: Chirp line from the northern sector of the RGT, showing the truncation of previously deposited prograding sediments. Light blue and yellow dashed lines are shown as references of the continuation of the strata. 
Solid Earth Discuss., https://doi.org/10.5194/se-2018-140

Manuscript under review for journal Solid Earth

Discussion started: 13 February 2019

(c) Author(s) 2019. CC BY 4.0 License.

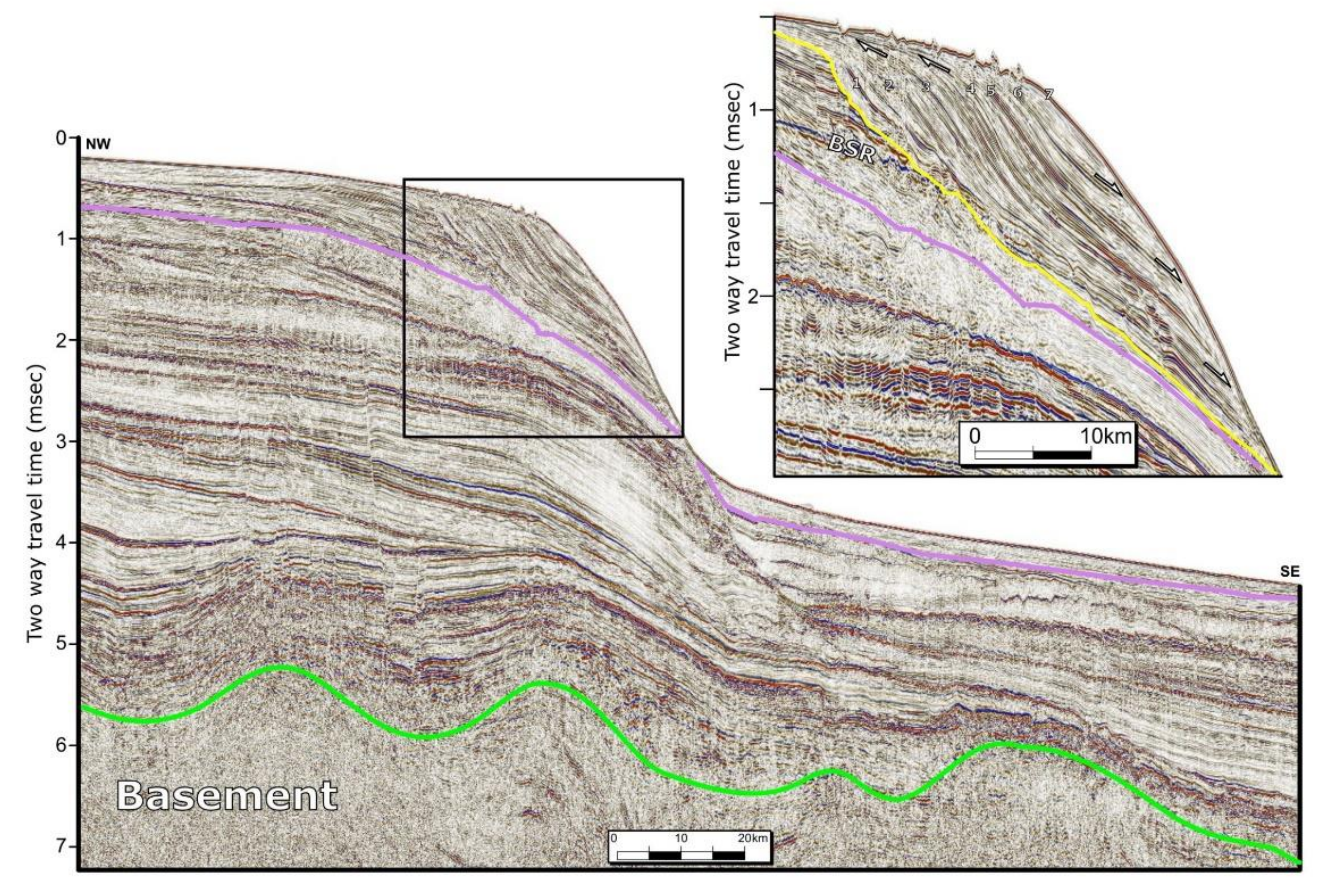

Figure 5: Deep seismic reflection line showing the whole post-Aptian sequence. Light green and magenta lines indicate the basement and Serravalian (Middle Miocene) discontinuities. The zoomed part shows a clinoform, truncated in its uppermost part. Internal high-amplitude reflectors probably reflect the limit of Pleistocene climatic cycles. 
Solid Earth Discuss., https://doi.org/10.5194/se-2018-140

Manuscript under review for journal Solid Earth

Discussion started: 13 February 2019

(c) Author(s) 2019. CC BY 4.0 License.

(c) (i)

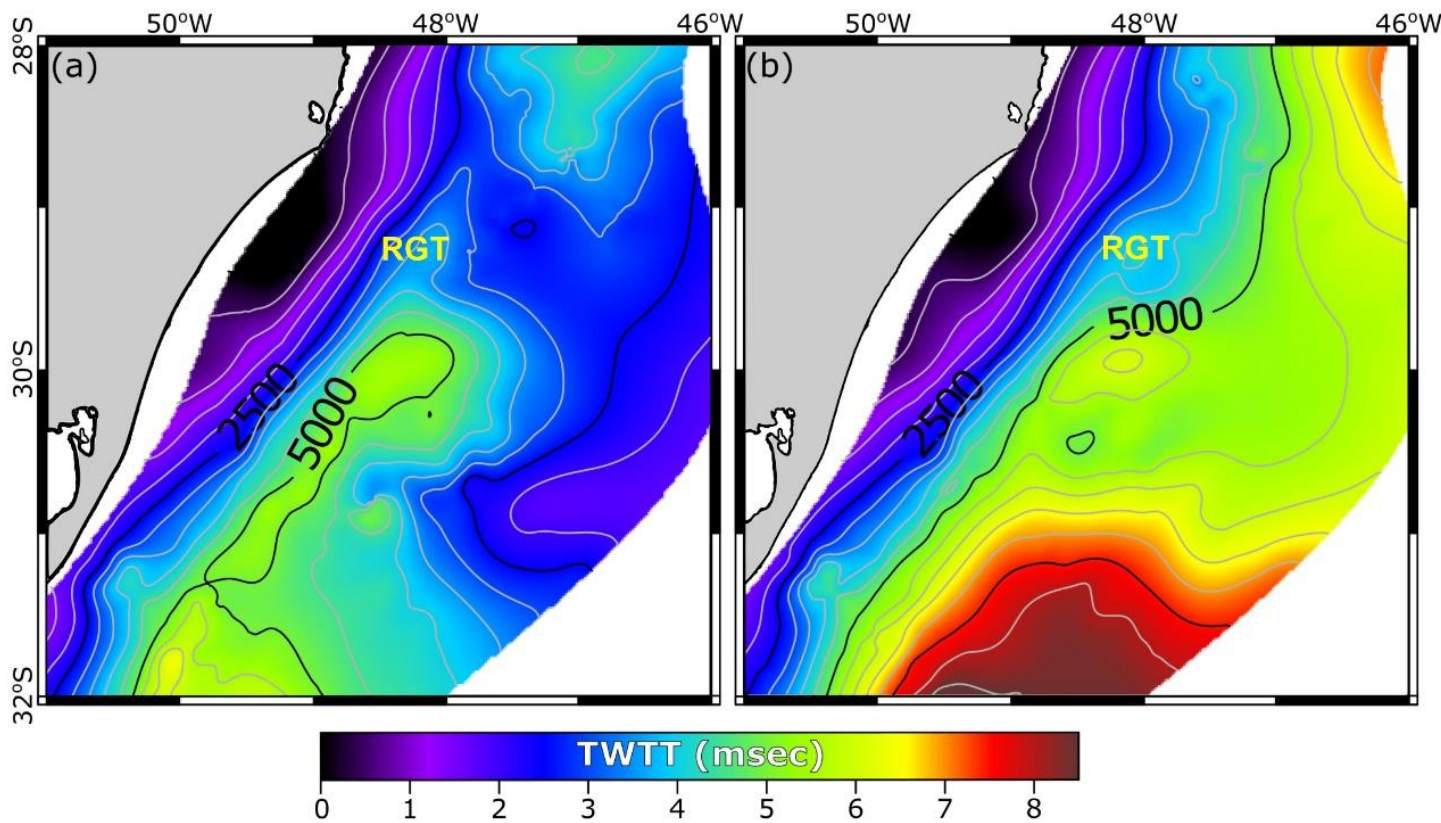

Figure 6: Maps of sediment isopach (left) and pre-Aptian depth (values in msec)
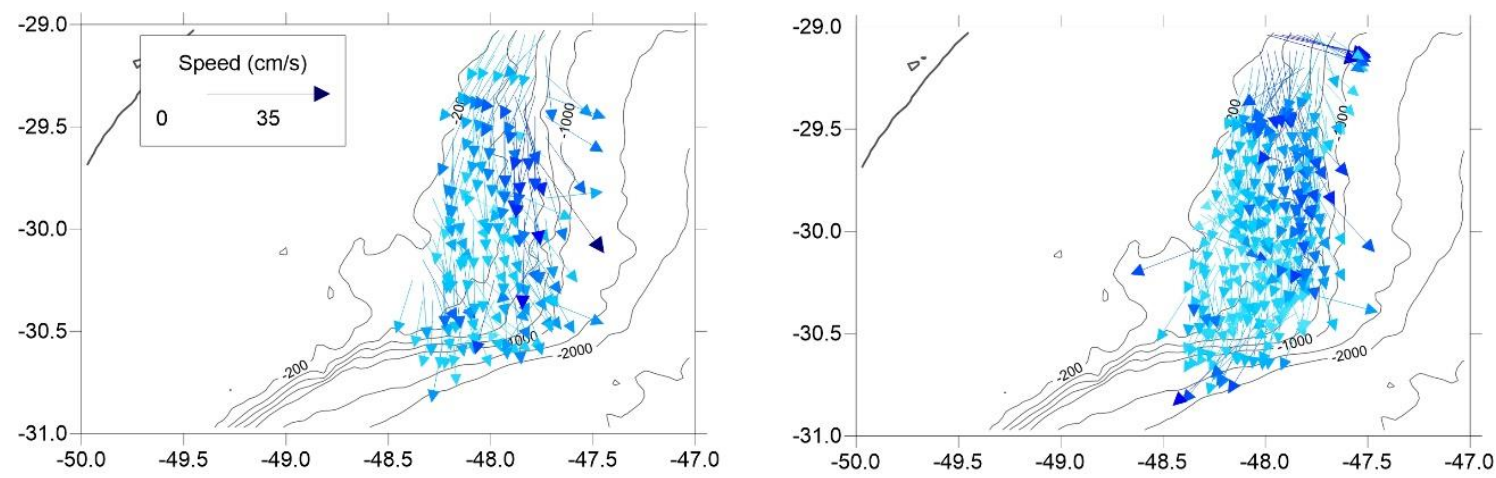

Figure 7: Vector maps of surface (left) and 200-meters (right), current speed and direction, interpolated from ADCP data collected

in a survey held in November-December 2017. 
Solid Earth Discuss., https://doi.org/10.5194/se-2018-140

Manuscript under review for journal Solid Earth

Discussion started: 13 February 2019

(c) Author(s) 2019. CC BY 4.0 License.

(c) (i)

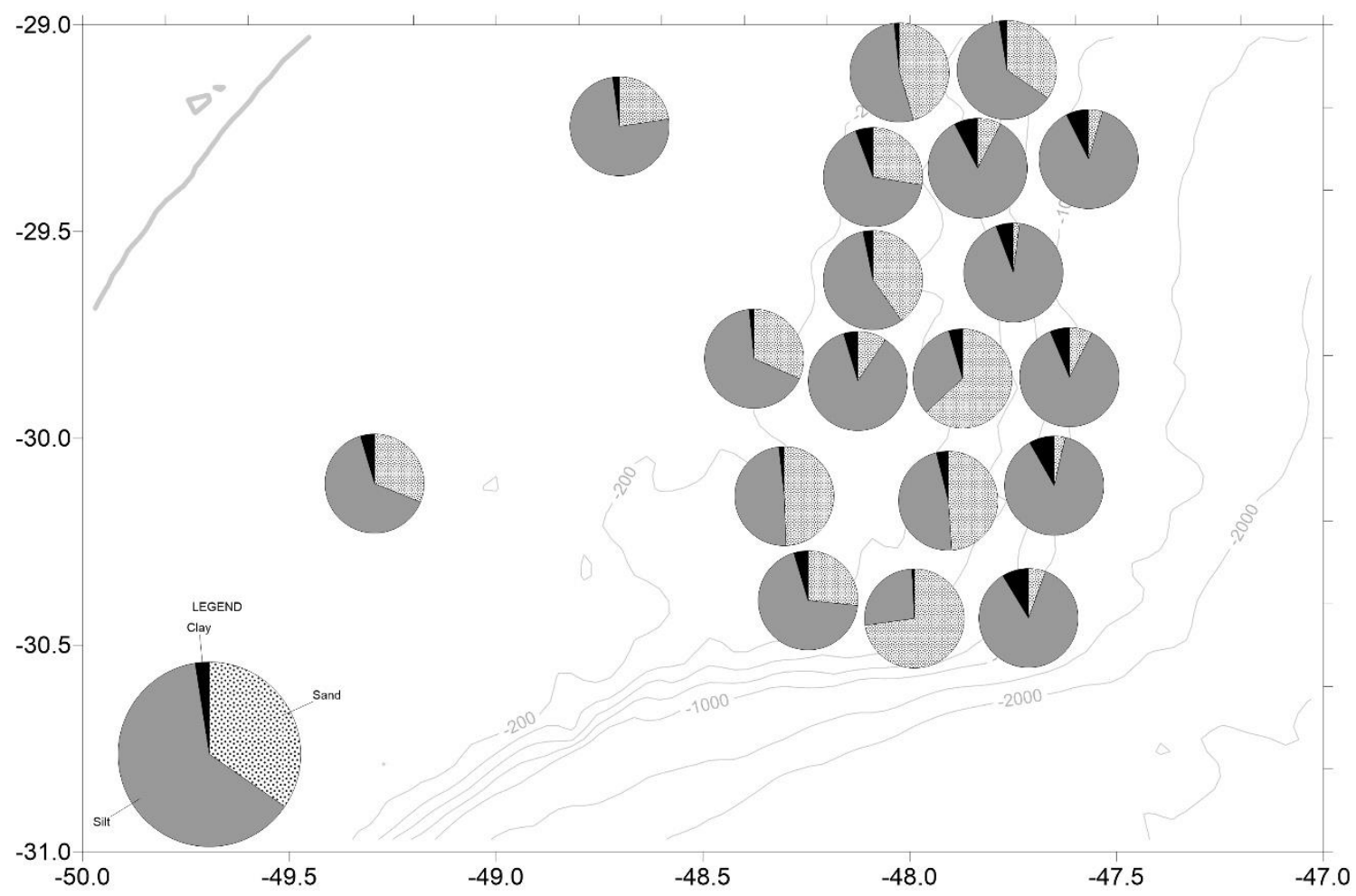

Figure 8: Distribution of pie-charts of sand-silt-clay in the study area. 
Solid Earth Discuss., https://doi.org/10.5194/se-2018-140

Manuscript under review for journal Solid Earth

Discussion started: 13 February 2019

(c) Author(s) 2019. CC BY 4.0 License.

(c) (i)

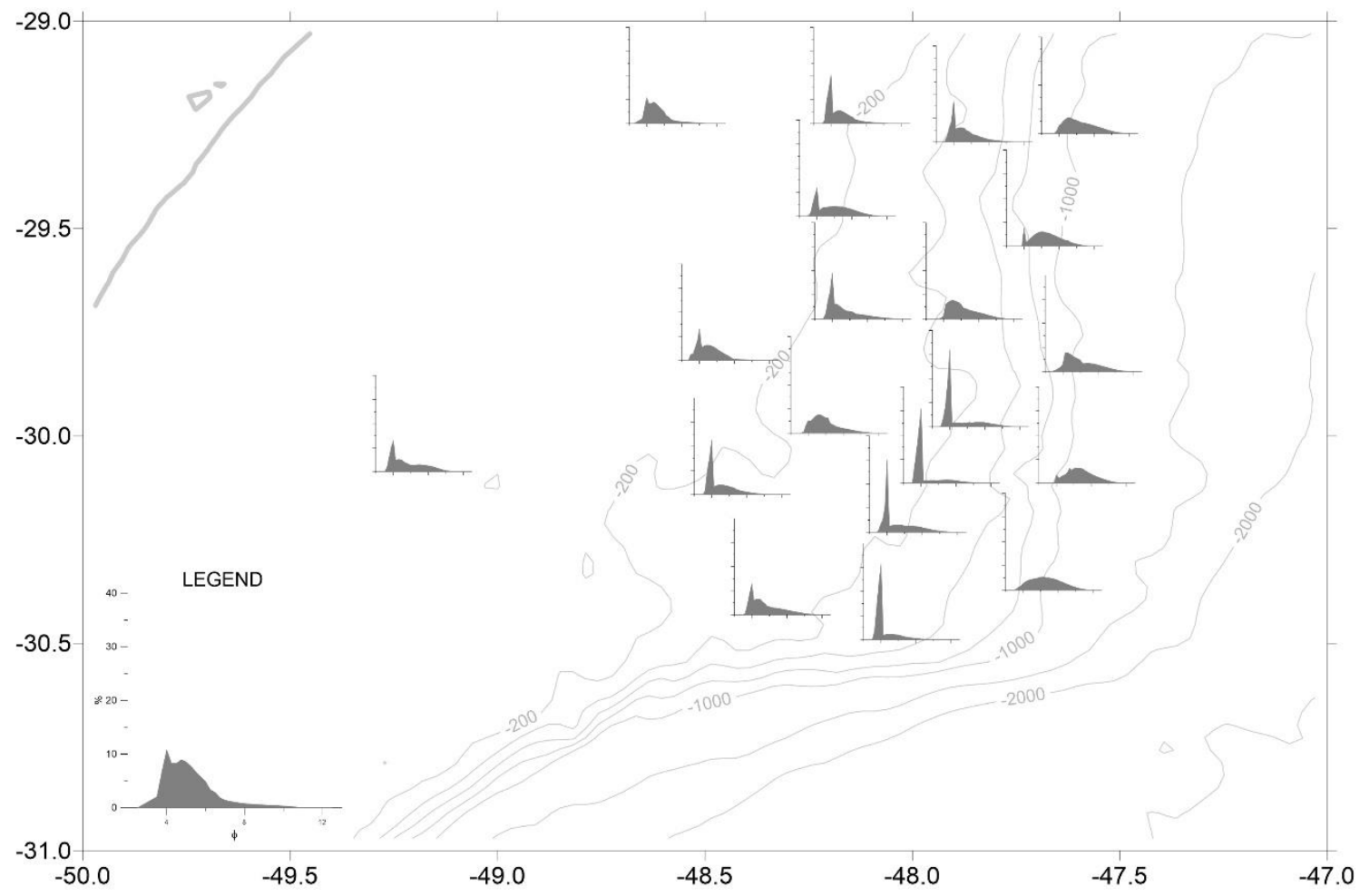

Figure 9: Grain-size distribution curves of the samples collected in the study area.

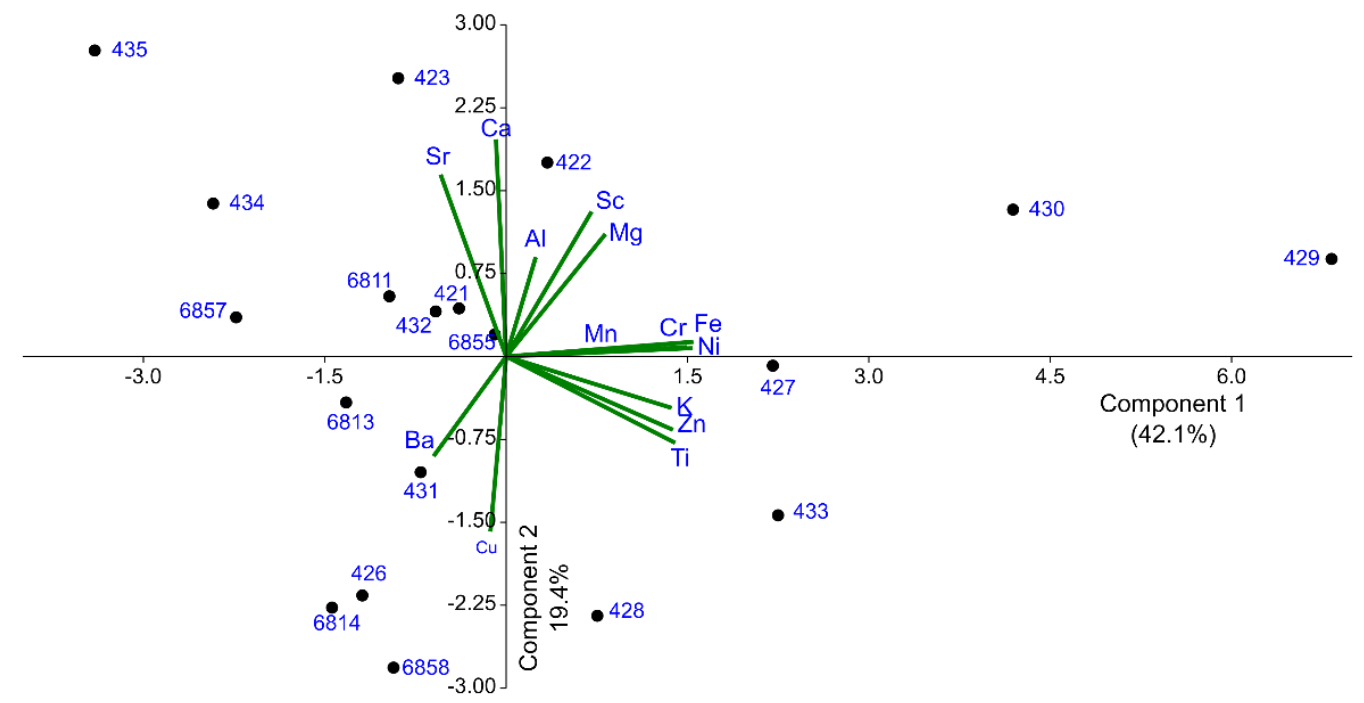

Figure 10: Scatter plot (samples and variables) of the two first components of the Principal Component Analysis. 
Solid Earth Discuss., https://doi.org/10.5194/se-2018-140

Manuscript under review for journal Solid Earth

Discussion started: 13 February 2019

(c) Author(s) 2019. CC BY 4.0 License.

(c) (i)

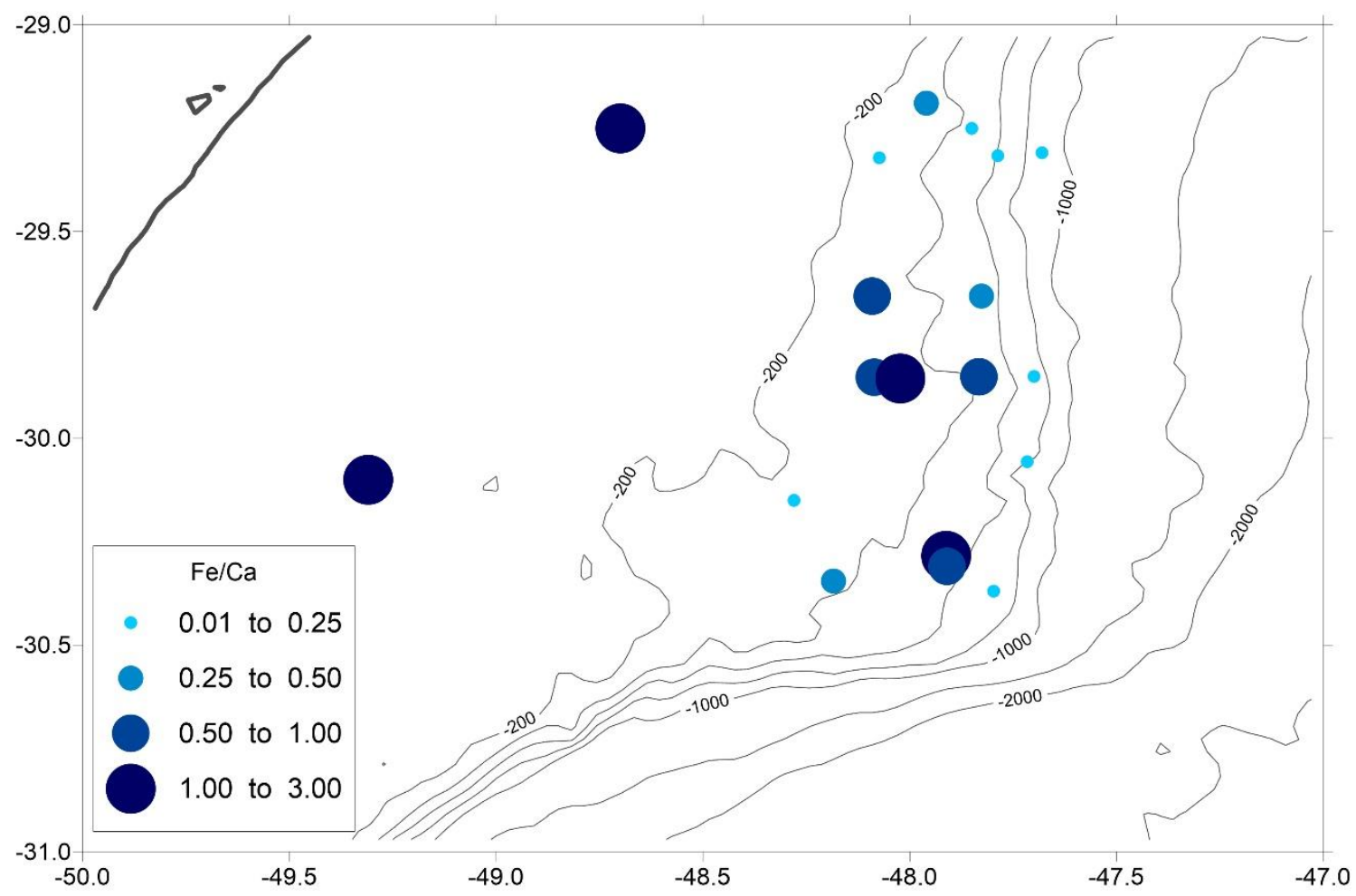

Figure 11: Distribution of the Fe/Ca ratio in surface sediment samples of the study area. 
Solid Earth Discuss., https://doi.org/10.5194/se-2018-140

Manuscript under review for journal Solid Earth

Discussion started: 13 February 2019

(c) Author(s) 2019. CC BY 4.0 License.

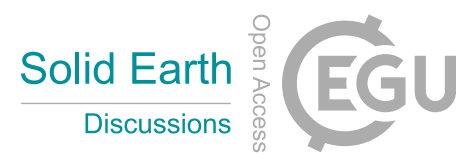

(c) (i)

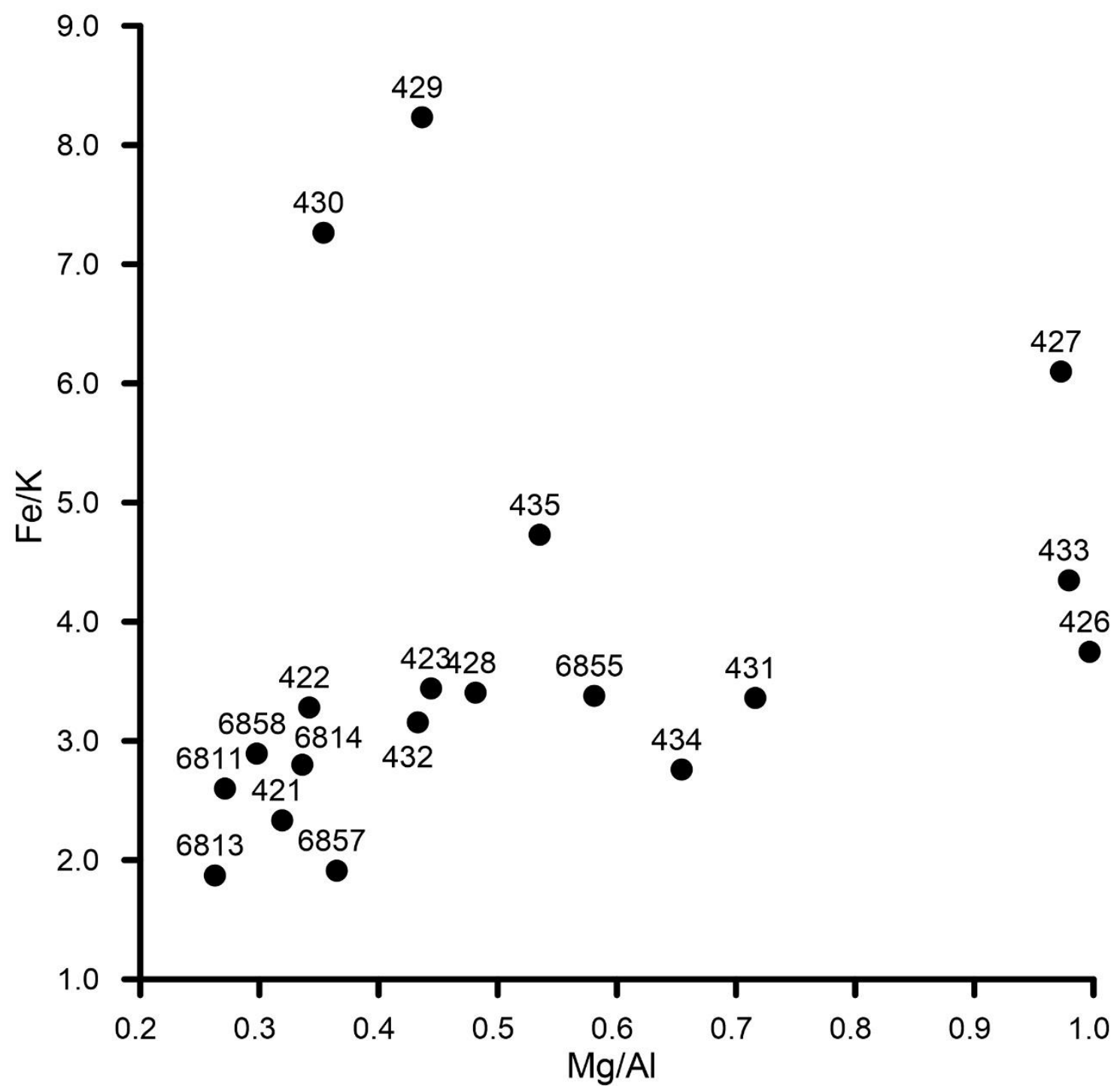

Figure 12. Scatter plot of $\mathrm{Fe} / \mathrm{K}$ versus $\mathrm{Mg} / \mathrm{Al}$ ratios of the surface sediment samples in the study area 
Solid Earth Discuss., https://doi.org/10.5194/se-2018-140

Manuscript under review for journal Solid Earth

Discussion started: 13 February 2019

(c) Author(s) 2019. CC BY 4.0 License.

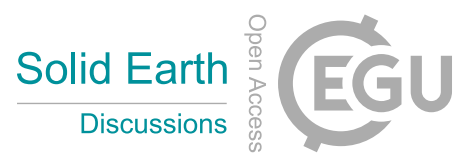

(c) (i)

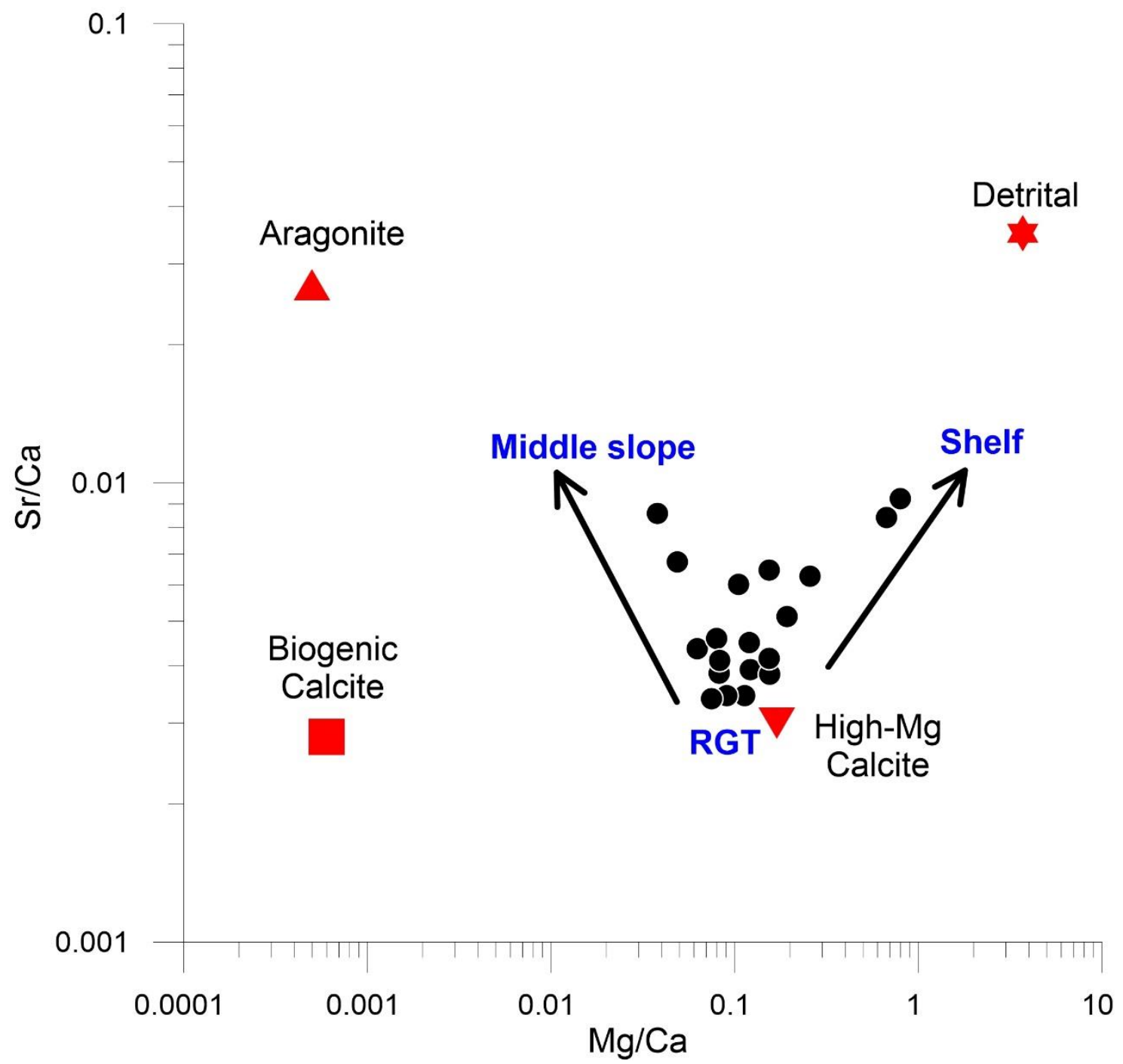

Figure 13. Scatter plot of the $\mathrm{Sr} / \mathrm{Ca}$ versus $\mathrm{Mg} / \mathrm{Ca}$ ratios of the surface sediments in the study area. Position of the end-members is based in Bayon et al. (2007). 
Solid Earth Discuss., https://doi.org/10.5194/se-2018-140

Manuscript under review for journal Solid Earth

Discussion started: 13 February 2019

(c) Author(s) 2019. CC BY 4.0 License.

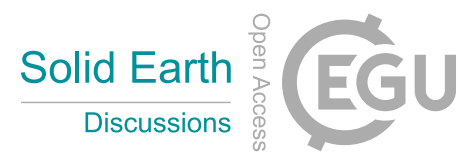

(c) (i)

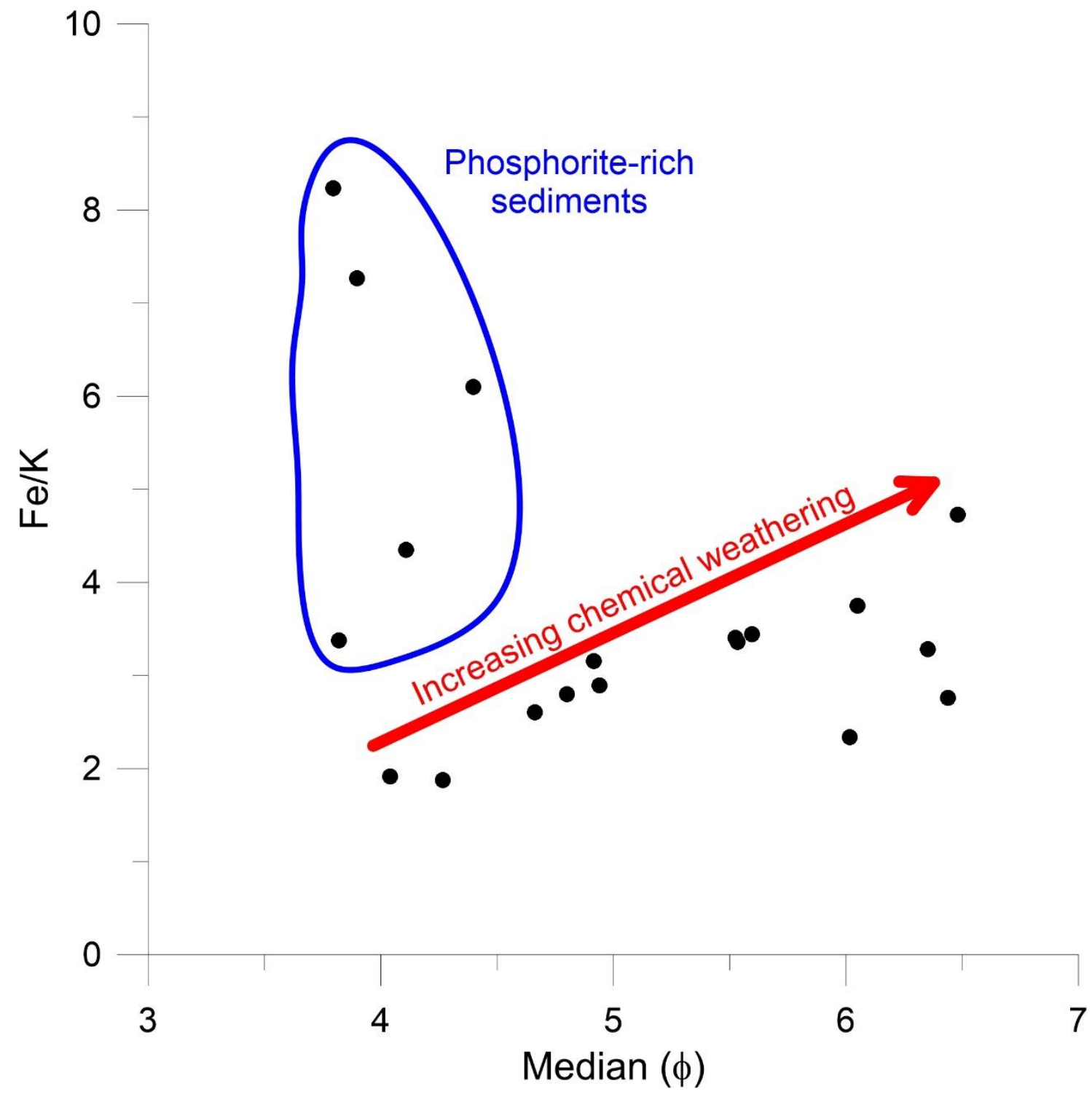

Figure 14. Scatter plot of $\mathrm{Fe} / \mathrm{K}$ ratio versus grain size median (in $\phi)$. The blue line encompasses the phosphorite-rich sediments. 
Solid Earth Discuss., https://doi.org/10.5194/se-2018-140

Manuscript under review for journal Solid Earth

Discussion started: 13 February 2019

(c) Author(s) 2019. CC BY 4.0 License.

(c) (1)

Table 1. Location of the sediment samples used in this work

\begin{tabular}{|r|r|r|r|}
\hline Station & Latitude & Longitude & Depth $(\mathrm{m})$ \\
\hline 421 & -29.31 & -47.68 & 888 \\
\hline 422 & -29.32 & -47.79 & 688 \\
\hline 423 & -29.32 & -48.07 & 234 \\
\hline 426 & -29.66 & -47.83 & 534 \\
\hline 427 & -29.66 & -48.09 & 344 \\
\hline 428 & -29.85 & -48.09 & 358 \\
\hline 429 & -29.86 & -48.02 & 348 \\
\hline 430 & -29.85 & -47.83 & 483 \\
\hline 431 & -29.85 & -47.70 & 800 \\
\hline 432 & -30.34 & -48.18 & 332 \\
\hline 433 & -30.28 & -47.91 & 490 \\
\hline 434 & -30.37 & -47.80 & 746 \\
\hline 435 & -30.06 & -47.72 & 797 \\
\hline 6811 & -29.25 & -47.85 & 506 \\
\hline 6813 & -29.19 & -47.96 & 299 \\
\hline 6814 & -29.25 & -48.70 & 103 \\
\hline 6821 & -29.83 & -48.21 & 232 \\
\hline 6855 & -30.31 & -47.91 & 500 \\
\hline 6857 & -30.15 & -48.28 & 240 \\
\hline 6858 & -30.10 & -49.31 & 100 \\
\hline
\end{tabular}


Solid Earth Discuss., https://doi.org/10.5194/se-2018-140

Manuscript under review for journal Solid Earth

Discussion started: 13 February 2019

(c) Author(s) 2019. CC BY 4.0 License.

(c) (1)

Table 2. Spearman $\rho$ correlation of the grain size and metals analyzed in this work

\begin{tabular}{|c|c|c|c|c|c|c|c|c|c|c|c|c|c|c|c|c|c|c|}
\hline & Depth & Sand & Silt & Clay & $\mathrm{Al}$ & $\mathrm{Ba}$ & $\mathrm{Ca}$ & $\mathrm{Cr}$ & $\mathrm{Cu}$ & $\mathrm{Fe}$ & $\mathrm{K}$ & $\mathrm{Mg}$ & $\mathrm{Mn}$ & $\mathrm{Ni}$ & Sc & $\mathrm{Sr}$ & $\mathrm{Ti}$ & $\mathrm{Zn}$ \\
\hline Depth & & 0.031 & 0.043 & 0.004 & & & 0.015 & & & & & & & & & 0.040 & & \\
\hline Sand & -0.483 & & 0.000 & 0.000 & & & & 0.011 & 0.005 & & 0.017 & & & & & & & \\
\hline Silt & 0.457 & -0.986 & & 0.000 & & & & 0.016 & 0.003 & & 0.024 & & & & & & & \\
\hline Clay & 0.609 & -0.827 & 0.762 & & & & 0.003 & & 0.031 & & & & & & & 0.012 & & \\
\hline $\mathrm{Al}$ & & & -0.182 & & & & & & & & & & & & 0.000 & & & \\
\hline $\mathrm{Ba}$ & & & & & & & & & 0.033 & & & & & & & & & \\
\hline $\mathrm{Ca}$ & 0.549 & & & 0.644 & & & & & & & & & 0.042 & & & 0.000 & & \\
\hline $\mathrm{Cr}$ & & 0.568 & -0.544 & & & & & & & 0.000 & 0.000 & & & 0.000 & & & 0.001 & 0.002 \\
\hline $\mathrm{Cu}$ & & -0.621 & 0.647 & 0.495 & & 0.491 & & & & & & & & & 0.002 & & & \\
\hline $\mathrm{Fe}$ & & & & & & & & 0.912 & & & 0.000 & 0.035 & 0.014 & 0.000 & & & 0.000 & 0.000 \\
\hline $\mathrm{K}$ & & 0.539 & -0.516 & & & & & 0.800 & & 0.882 & & 0.009 & & 0.000 & & & 0.000 & 0.009 \\
\hline $\mathrm{Mg}$ & & & & & & & & & & 0.486 & 0.582 & & 0.003 & & & & & \\
\hline $\mathrm{Mn}$ & & & & & & & 0.470 & & & 0.553 & & 0.642 & & 0.007 & & & 0.030 & \\
\hline $\mathrm{Ni}$ & & & & & & & & 0.860 & & 0.891 & 0.746 & & 0.598 & & & & 0.000 & 0.000 \\
\hline Sc & & & & & 0.837 & & & & -0.658 & & & & & & & & & \\
\hline $\mathrm{Sr}$ & 0.475 & & & 0.561 & & & 0.946 & & & & & & & & & & & \\
\hline $\mathrm{Ti}$ & & & & & & & & 0.696 & & 0.767 & 0.742 & & 0.498 & 0.798 & & & & 0.000 \\
\hline $\mathrm{Zn}$ & & & & & & & & 0.667 & & 0.730 & 0.584 & & & 0.856 & & & 0.793 & \\
\hline
\end{tabular}

